\title{
Soil and Water Conservation in Burkina Faso, West Africa
}

\author{
Clement Nyamekye ${ }^{1,2, *}$, Michael Thiel ${ }^{3}$, Sarah Schönbrodt-Stitt ${ }^{3}$, Benewinde J.-B. Zoungrana ${ }^{4}$ \\ and Leonard K. Amekudzi ${ }^{5}$ \\ 1 WASCAL Graduate Research Programme on Climate Change and Land Use, Kwame Nkrumah University \\ of Science and Technology, University Post Office Box PMP, 00233 Kumasi, Ghana \\ 2 Department of Civil Engineering, Koforidua Technical University, P.O. Box KF 981, 00233 Koforidua, Ghana \\ 3 Department of Remote Sensing, Institute of Geography and Geology, University of Würzburg, \\ Oswald-Külpe-Weg 86, 97074 Würzburg, Germany; michael.thiel@uni-wuerzburg.de (M.T.); \\ sarah.schoenbrodt-stitt@uni-wuerzburg.de (S.S.-S.) \\ 4 West African Science Service Center on Climate Change and Adapted Land Use, \\ Avenue Mouammar Kadhafi, 06 BP 9507 Ouagadougou, Burkina Faso; beneboscoh@gmail.com \\ 5 Department of Physics, Kwame Nkrumah University of Science and Technology, University Post Office Box \\ PMB, 00233 Kumasi, Ghana; Leonard.Amekudzi@gmail.com \\ * Correspondence: nyamekyeclement@gmail.com; Tel.: +233-265-120164
}

Received: 7 July 2018; Accepted: 26 August 2018; Published: 6 September 2018

check for updates

\begin{abstract}
Inadequate land management and agricultural activities have largely resulted in land degradation in Burkina Faso. The nationwide governmental and institutional driven implementation and adoption of soil and water conservation measures (SWCM) since the early 1960s, however, is expected to successively slow down the degradation process and to increase the agricultural output. Even though relevant measures have been taken, only a few studies have been conducted to quantify their effect, for instance, on soil erosion and environmental restoration. In addition, a comprehensive summary of initiatives, implementation strategies, and eventually region-specific requirements for adopting different SWCM is missing. The present study therefore aims to review the different SWCM in Burkina Faso and implementation programs, as well as to provide information on their effects on environmental restoration and agricultural productivity. This was achieved by considering over 143 studies focusing on Burkina Faso's experience and research progress in areas of SWCM and soil erosion. SWCM in Burkina Faso have largely resulted in an increase in agricultural productivity and improvement in food security. Finally, this study aims at supporting the country's informed decision-making for extending already existing SWCM and for deriving further implementation strategies.
\end{abstract}

Keywords: soil and water conservation; environmental degradation; agricultural productivity; food security; soil erosion; Burkina Faso

\section{Introduction}

Soil and water are the most precious resources in agriculture. Particularly in the context of global change (i.e., climate change, population growth, deforestation, urban sprawl, intensive agricultural use, and the displacement of subsistence farming to marginal lands) and the important discourse on food security [1], there is an urgent need to address both by adequate conservation measures. As stated in the World Water Development Report by the United Nations, the world has never been thirstier [2]. This alarming scenario sets the framework for global action.

Already, $27 \%$ of the total land area of the African continent is degraded. Of this, $65 \%$ is agricultural land. Predominantly, land degradation resulting in declined agricultural productivity is due to soil 
erosion and further processes such as chemical (e.g., depletion of chemical stores of soil through mining) and physical (e.g., rill erosion) soil degradation [3-6]. Soil erosion by water and wind is a serious environmental problem in Africa [7]. It is mostly caused by physiographic factors such as harsh climatic conditions and the unstable structure of the soil, but also by socio-economic factors such as increased pressure on the land resources [8-10]. The harsh climatic conditions refer to the extreme events of abundant rainfall following periods of drought, which affect the soil by lowering its resistance (i.e., soil erodibility) against the impact of splash, therefore favoring higher runoff potential. Erodible soil textures such as silty and clayey loam make the soil highly vulnerable to particle detachment and transport. Poor soil management practice coupled with inappropriate conservation measures even trigger these processes. [11]. Soil erosion results in nutrient loss and desertification in most semi-arid areas, such as in West Africa [12-14]. It is also a major environmental threat affecting food security, income, and environmental health, particularly in the tropical and subtropical countries [12,15-17].

Burkina Faso in West Africa is characterized by the occurrence of only a few natural resources and has a weak industrial base. Most of its population is involved in subsistence farming. The country has a population growth rate of $3.1 \%$, which is recorded to be one of the highest in the world. The growth has tripled in the last 30 years [18]. The estimated population of Burkina Faso in 2018 was 19.5 million [19]. Most of the fragile lands in the country have a population density of around 100 people per $\mathrm{km}^{2}$, which puts much pressure on the limited resources in the country, resulting in environmental stress [20]. The increasing population, resulting in a growing demand for food, raises concern about the agricultural lands in the country [21]. The main concerns refer to the increasing demand for the area to be cultivated coupled with Best Management Practices (BMPs) in agriculture to meet this momentum of growing demand [22]. Increasing the area of cultivation would result in the destruction of natural vegetation cover [23]. Subsequently, more land area is put at risk in terms of soil erosion and other natural disasters [24]. Food insecurity is a serious threat in most parts of Burkina Faso [25]. It predominantly results from poor management practices (e.g., by bush burning), which often lead to soil erosion and the subsequent loss of fertile topsoil, thereby rendering valuable agricultural land unsuitable for crop production [26-28]. It is also indirectly due to an increasing number of drought events contributing to land degradation and again affecting most of the agricultural lands [29]. According to Dialla [30] and Forkuo et al. [31], land degradation in Burkina Faso has been a major problem in the past five decades (1960 to 2010). Attempts to address the problem began in the early 1960s from the Yatenga Province in the northern part of the country.

The issue of soil erosion has been a major obstacle for sustained and integrated socio-economic development for farmers in Burkina Faso. This situation compelled them to develop Soil and Water Conservation measures (SWCM) purposely for runoff control, soil moisture improvement, land rehabilitation, and nutrient management [32]. At the beginning of implementation, the types of SWCM applied varied from place to place and were always supposed to be based on conditions such as average rainfall amount and intensity, soil type, and topography. SWCM have been practiced by farmers for several decades [30] to mitigate the dimension and risk of land degradation; however, they became more effective and result-oriented when government and non-governmental organizations (NGOs) provided support to combat the environmental threat in the early 1980s [32,33]. This collaboration helped in efficiently implementing SWCM by farmers. Also, the persistent increase in soil losses by erosive action necessitated the implementation of politically driven strategies and initiatives (e.g., community driven development (CDD) in 2004 and UN-Millennium project in 2005) to curtail its adverse impacts in Burkina Faso. The implementation of SWCM resulted in the transformation of large areas of arid landscape into productive agricultural land, which enhanced food security for about three million people [32].

In recent years, many reviews have been conducted in other parts of Africa, reporting the effectiveness of SWCM [34,35], such as on regenerating vegetation, rehabilitating the soil [36], and reducing sediment yield [34,37], but also stating difficulties in implementing SWCM, as done for 
Ethiopia [38,39]. Yet, results from the reviews showed that SWC is not properly recorded, thus making it difficult to be sufficiently addressed by policy makers in decision making processes.

A thorough review addressing the various aspects of SWCM mentioned is absent in Burkina Faso. Moreover, there is no comprehensive review to access the major setbacks of the past and current SWCM to help improve the future development of SWCM at both rural and national scales. The present study therefore aims to review the different SWCM in Burkina Faso and implementation programs, as well as provide information on their effects on environmental restoration and agricultural productivity. This was assessed by reviewing 143 studies considered in areas of SWCM and soil erosion in Burkina Faso. Reviewed studies comprise scientific articles, conference papers, reports, and technical notes from the government and NGOs on both soil erosion and SWC measures.

Thus, the objective of this paper is (i) to review the factors, causes, and impacts of land degradation in Burkina Faso; (ii) to highlight how the various governmental and institutional initiatives drive the implementation of SWCM in the country; and (iii) to shed light on the lessons learnt in SWC implementation in Burkina Faso.

\section{Study Area}

Burkina Faso, formerly called Upper Volta, is a landlocked country in West Africa. It is located between latitudes $9^{\circ} 24^{\prime} 20^{\prime \prime} \mathrm{N}$ to $15^{\circ} 06^{\prime} 30^{\prime \prime} \mathrm{N}$ and longitudes $5^{\circ} 30^{\prime} 50^{\prime \prime} \mathrm{W}$ to $2^{\circ} 24^{\prime} 30^{\prime \prime}$ E. Approximately $75 \%$ of the country is located on the Sahelian peneplain, thus the topography is mainly flat to gently undulating with a few isolated hills [40]. The average altitude is $400 \mathrm{~m}$ a.s.l., with $749 \mathrm{~m}$ a.s.l., representing Mountain Tenakourou located at Koutiala plateau in southwestern Burkina Faso, as the highest peak.

From a climatology perspective, Burkina Faso is grouped into three climatic zones. These are: (i) the Sahel in northern Burkina Faso; (ii) the Sudan-Sahel largely covering central Burkina Faso; and (iii) the Sudan-Guinea stretching from the southwest to the southernmost country (Figure 1a). Predominant vegetation in the Sahel is grassland characterized by mostly annual species and a sparse woody cover [41]. The Sahel is characterized by natural vegetation mainly composed of wooded grassland and deciduous shrubland inter-sparsed with trees [42]. The Sudan-Guinea typically exhibits natural vegetation with dense deciduous shrubs and woodland, in addition to agroforestry parklands [43]. According to Callo-Concha et al. [44], this zone is mostly suitable for agriculture production.

Burkina Faso has a tropical climate with two alternating seasons. The country's rainy season spans from May to October ([31,45]; Figure 2e). Average annual rainfall (1980 to 2016) ranges from $250 \mathrm{~mm}$ in the north to approximately $1100 \mathrm{~mm}$ in the south [46]. Average monthly temperatures vary from $23{ }^{\circ} \mathrm{C}$ to $34{ }^{\circ} \mathrm{C}$ in the north, and to $25{ }^{\circ} \mathrm{C}$ to $31^{\circ} \mathrm{C}$ in the south [47]. Average annual potential evapotranspiration is approximately $1875 \mathrm{~mm}$ and almost constant from one year to the other [48], thus indicating a negative water balance throughout the years. Topsoils in most parts of the country predominantly comprise an erodible texture such as sand-clay-loam, loam, and sandy-loam ([49]; Figure 3). 


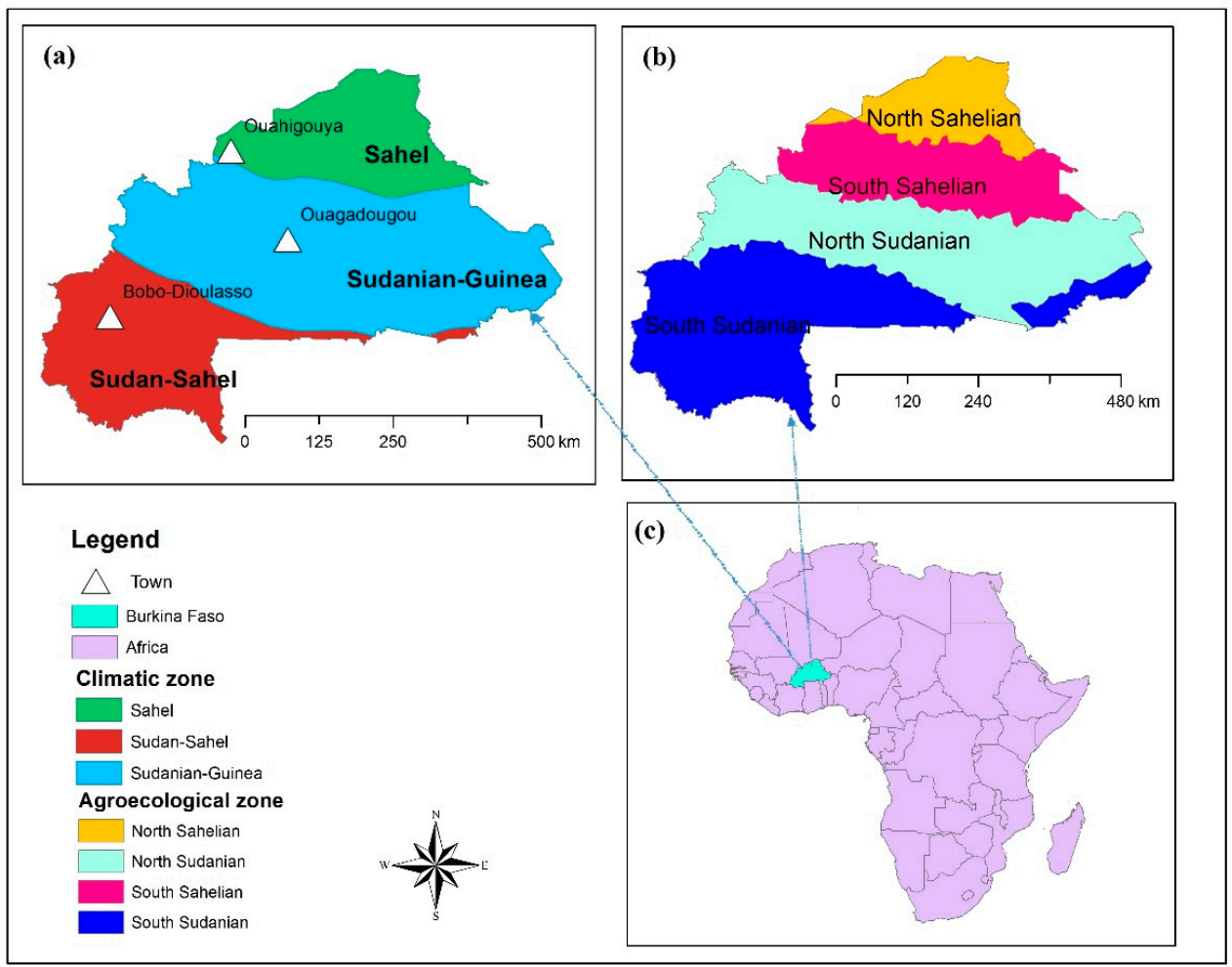

Figure 1. (a) climatic zones (b) agro-ecological zones (c)Regional boundaries of Burkina Faso [50].

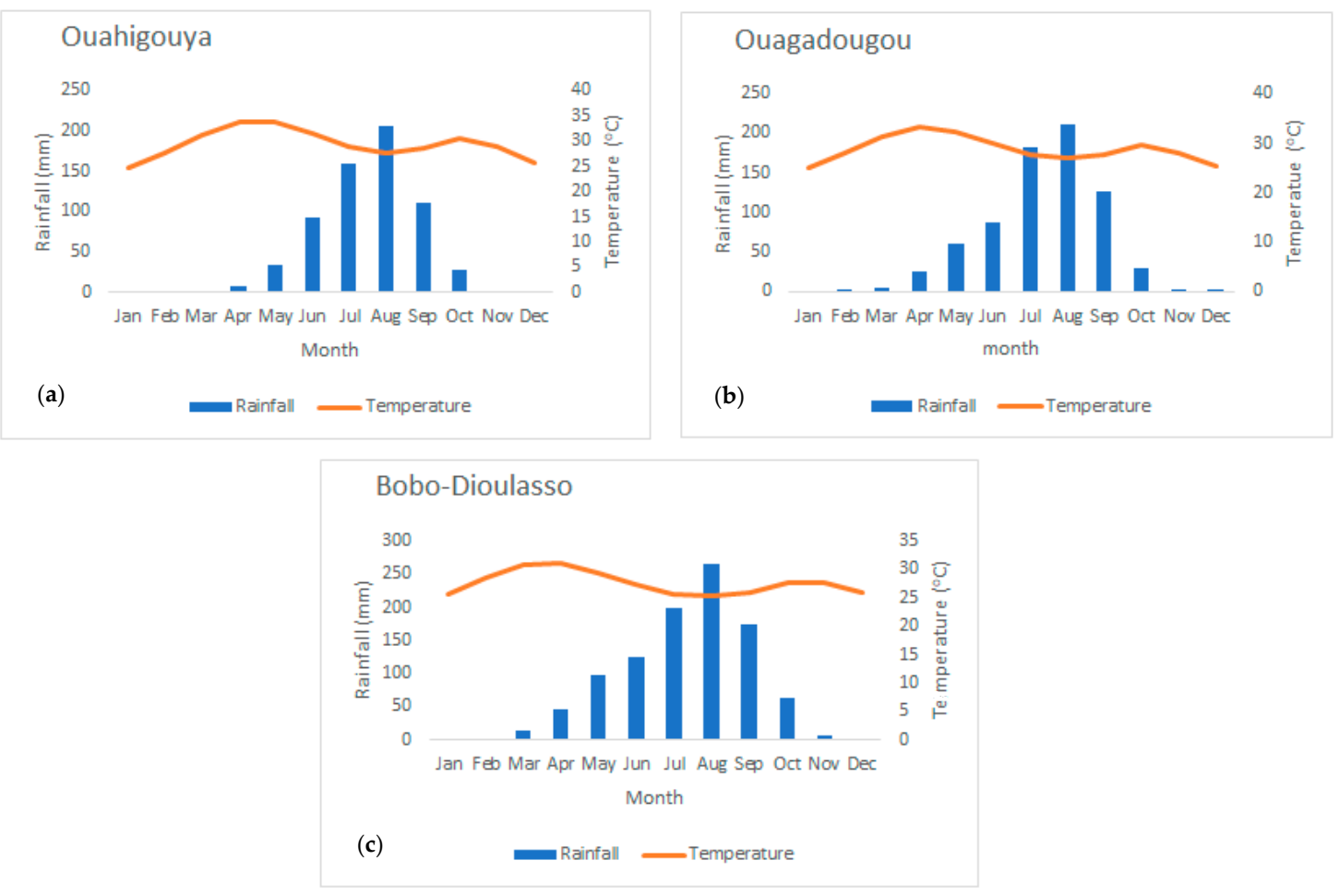

Figure 2. Long-term (1980-2012) average rainfall (mm) and Temperature $\left({ }^{\circ} \mathrm{C}\right)$ per month for the climatic zones of (a) Sahel, represented here with the city of Ouahigouya; (b) Sudanian-Guinea, represented here with the city of Ouagadougou; and (c) Sudan-Sahel, represented here with the city of Bobo-Dioulasso [51]. 


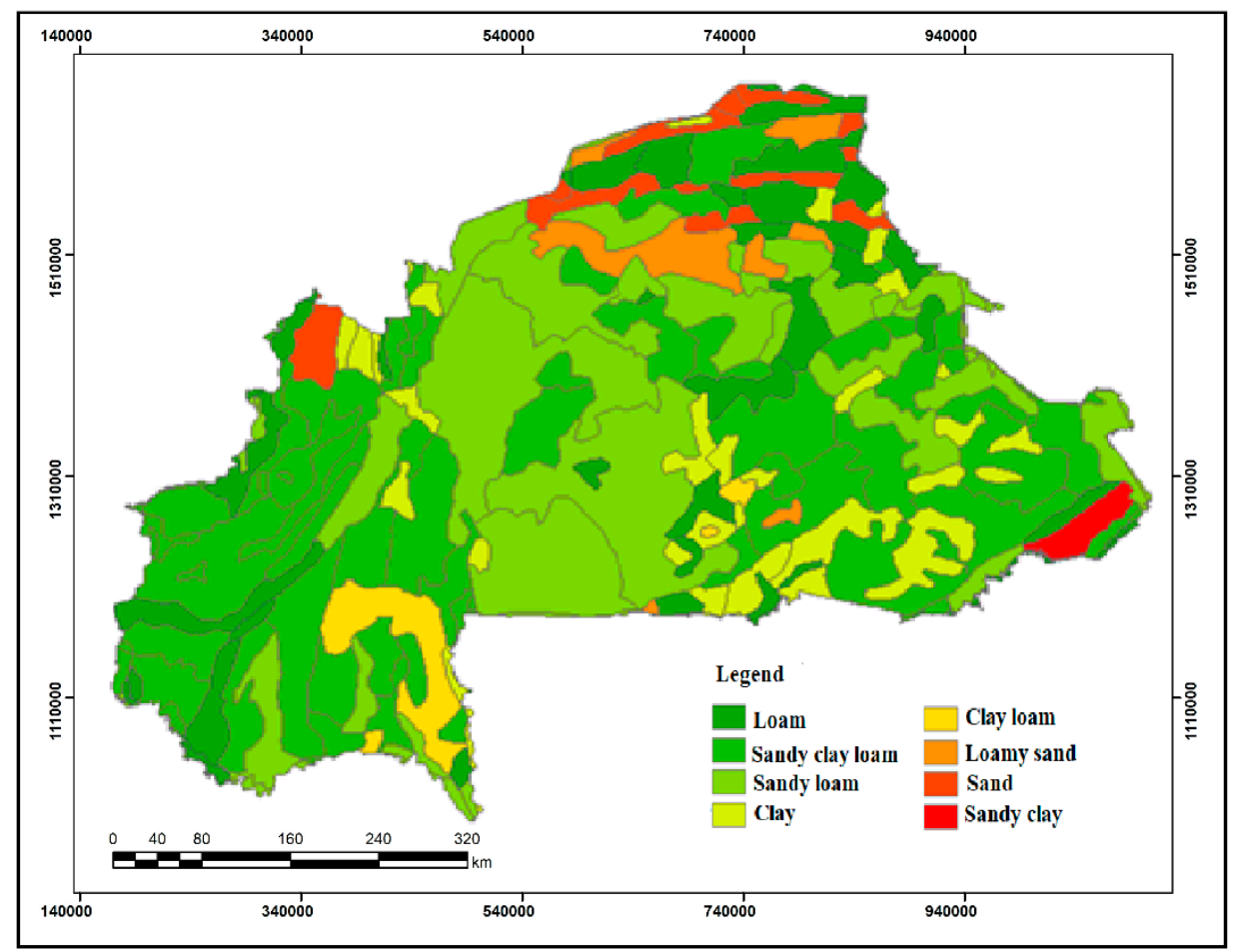

Figure 3. Soil texture map of Burkina Faso [49].

\section{Soil and Water Conservation Initiatives in Burkina Faso}

Soil and water conservation measures (SWCM) can be defined as activities used to preserve and improve the capacity of land productivity, such as the soil, water, and vegetation in degraded areas [52]. The severity of soil erosion and degradation in the 1970s and 1980s prompted the government to collaborate with non-governmental organizations (NGOs) to come up with various Soil and Water Conservation (SWC) initiatives (Table 1) to support the rehabilitation of degraded lands. According policies and initiatives have undergone various transformations in terms of approach, technologies, and technical standards [24]. Few of these policies include a five-year Popular Development Program (1986-1990), which placed emphasis on conservation, protection, and restoration of the environment (Table 1). The Agrarian Land Re-organization (ALR) was also introduced in 1984 (Table 1) and focused on distributing land among the inhabitants of villages by giving them long-term rights of occupation, as well as guaranteeing them land tenure security [24]. The inhabitants willingly implemented SWCM to protect their lands since they felt a sense of ownership of the land. The National Program for Combating Desertification (PNLCD), which outlines national strategies for a more focused intervention in relation to the environment, was also instituted in 1986. It also recommended ways of implementing, coordinating, monitoring, and evaluating strategies through forming an executive body, the Committee for Combating Desertification (CNLCD). Other initiatives such as the Programme Sahel Burkina (PSB), Combating Desertification in Burkina (LUCODEB), and the National Programme for the Management of Rural Areas (PNGT), were also launched by the government to run in parallel with the PNLCD. These initiatives aimed to directly or indirectly contribute to combatting desertification and restoring eroded soils. The Village forestry initiative (Table 1) aimed at finding solutions to restore, preserve, and protect natural lands in the provinces of the north, north-west, north-east, center, central-east, and south-east [24]. This initiative was specifically instituted by NGOs such as Association des Volontaires François pour le Progrées (AVFP), American Peace Corps, German Voluntary Services (SVA), Dutch Volunteer Services (SVN), OXFAM, AFRICARE, and 6 " $\mathrm{S}$ ". 
Table 1. Soil and water conservation (SWC) initiatives in Burkina Faso and their year of implementation, measure implemented, and area of implementation.

\begin{tabular}{lclll}
\hline \multicolumn{1}{c}{ Name of Initiative } & $\begin{array}{c}\text { Year of } \\
\text { Implementation }\end{array}$ & Objective & $\begin{array}{c}\text { SWC Measures } \\
\text { Implemented }\end{array}$ & $\begin{array}{c}\text { Area of } \\
\text { Implementation }\end{array}$ \\
\hline $\begin{array}{l}\text { Agrarian Land } \\
\text { Re-organization (ALR) }\end{array}$ & 1984 & Tenure security & $\begin{array}{l}\text { Agroforestry (wind } \\
\text { breaks), stone bund, zai }\end{array}$ & Nationwide \\
\hline $\begin{array}{l}\text { Five-year Popular } \\
\text { Development Program }\end{array}$ & 1986 & $\begin{array}{l}\text { Environmental } \\
\text { conservation, } \\
\text { protection, } \\
\text { and restoration }\end{array}$ & $\begin{array}{l}\text { Stone bund, zai, } \\
\text { half-moon and } \\
\text { agroforestry }\end{array}$ & Nationwide \\
\hline $\begin{array}{l}\text { National Program for } \\
\text { Combating Desertification } \\
\text { (PNLCD) }\end{array}$ & 1986 & $\begin{array}{l}\text { Conservation of } \\
\text { natural resources }\end{array}$ & $\begin{array}{l}\text { Mulching, agroforestry, } \\
\text { zai and half-moon }\end{array}$ & Nationwide \\
\hline $\begin{array}{l}\text { Program Sahel Burkina (PSB) } \\
\text { \& Combating Desertification } \\
\text { in Burkina Faso (LUCODEB) }\end{array}$ & 1992 & $\begin{array}{l}\text { Restoration of soil and } \\
\text { combat desertification }\end{array}$ & Zai and half-moon & Sahel and \\
\hline $\begin{array}{l}\text { National Program for the } \\
\text { Management of Rural Areas } \\
\text { (PNGT) }\end{array}$ & 1992 & $\begin{array}{l}\text { Control and reverse } \\
\text { the process of land } \\
\text { degradation }\end{array}$ & $\begin{array}{l}\text { Agroforestry, zai, } \\
\text { half-moon and } \\
\text { mulching }\end{array}$ & Nationwide \\
\hline $\begin{array}{l}\text { Reduce excessive } \\
\text { woodcutting and } \\
\text { restore damaged } \\
\text { eco-systems }\end{array}$ & Agroforestry & Nationwide \\
\hline
\end{tabular}

Although the initiatives were considered as successful at the early stages of implementation, they were bewildered with challenges after a few years of realization. Factors that contributed to these challenges included poor planning, a lack of education, limited incentives and benefits, technology choice, and community participation.

First among the challenges is how the government and initiatives place much importance on the documentation of the initiative for political expediencies, but pay little attention to the design and implementation stage of SWCM. The design and implementation are faced with interference from the traditional systems and beliefs of the farmers [53]. This results in the failure of the initiative since the awareness, mobilization, and active participation of the farmers were not considered. Additionally, failure to seek the indigenous knowledge of the farmers in the communities during the design stage makes it difficult for the farmers to adopt the new SWCM since they do not feel part of the process [54]. For example, the agro-forestry project (PAF) that started in the Yatenga region of Burkina Faso was successful in slowing and filtering runoff as the initiative was built on already existing old traditional stone bunds [53]. The approach of incorporating indigenous knowledge and building on already existing local measures also led to significant improvement for other regions in Burkina Faso [55-57]. The initiatives are only sustainable when the primary beneficiaries (farmers) are part of the decision-making processes. This makes them active and ensures the proper implementation of SWCM as part of BMPs.

\subsection{Types of Soil and Water Conservation Measures in Burkina Faso}

Both soil erosion by water and wind has been a major problem for farmers in Burkina Faso. This situation has compelled the farmers to develop strategies on SWCM purposely for runoff control, soil moisture improvement, and nutrient management [32]. The use of traditional SWCM started several decades ago in northwestern and northern parts of Burkina Faso [58-60]. Different types of SWCM covering various climatic zones of Burkina Faso have been developed over the years (Table 2). In areas with a high rainfall intensity, surface runoff and leaching of nutrients may occur as major threats for agricultural production, which makes SWCM such as stone bunds important in these areas. On the contrary, in drier areas (Sahel and northern part of the Sudan-Sahel), different types of SWCM 
such as half-moons (c.f., Section 3.1.1) and zai (c.f., Section 3.1.4) were designed and implemented to focus on harvesting and retaining water for crop irrigation.

The implementation of SWCM by the government and NGO's failed in the 1970's in most rural communities in Ouahigouya because of a lack of consideration of the preferences, skills, and involvement of the local farmers in planning [61]. This situation facilitated the involvement of the expertise of the local farming population, in order to ensure sustainable development of the SWC [62-64].

The common SWCM used to control soil erosion and to rehabilitate the land productivity in Burkina Faso include stone bunds, improved traditional planting pits (zai), mulching, half-moons, and agroforestry [65-69], as given in Table 2.

Table 2. Overview of soil and water conservation (SWC) measures that are predominant in Burkina Faso.

\begin{tabular}{llll}
\hline \multicolumn{1}{c}{ SWC } & $\begin{array}{c}\text { Year of } \\
\text { Implementation }\end{array}$ & $\begin{array}{c}\text { Climatic Zone } \\
\text { Commonly Found }\end{array}$ & \multicolumn{1}{c}{ Purpose } \\
\hline $\begin{array}{l}\text { half-moon } \\
\text { (see Section 3.1.1) }\end{array}$ & 1958 & Sahel and Sudan-Sahel & $\begin{array}{l}\text { Collects run-off water and } \\
\text { increase infiltration }\end{array}$ \\
\hline $\begin{array}{l}\text { zai } \\
\text { (Section 3.1.2) }\end{array}$ & 1980 & $\begin{array}{l}\text { Some part of Sahel and } \\
\text { part of Sudan-Sahel }\end{array}$ & $\begin{array}{l}\text { Rehabilitates barren and highly } \\
\text { degraded soils }\end{array}$ \\
\hline $\begin{array}{l}\text { stone bund } \\
\text { (Section 3.1.3) }\end{array}$ & $\begin{array}{l}\text { Late 1970s and } \\
\text { early 1980s }\end{array}$ & $\begin{array}{l}\text { Sahel, Sudan-Sahel, } \\
\text { and Sudan-Guinea }\end{array}$ & $\begin{array}{l}\text { Water harvesting technique, reduces runoff } \\
\text { and improves infiltration }\end{array}$ \\
\hline $\begin{array}{l}\text { agroforestry } \\
\text { (Section 3.1.4) }\end{array}$ & 1970 & $\begin{array}{l}\text { Sahel, Sudan-Sahel, } \\
\text { and Sudan-Guinea }\end{array}$ & $\begin{array}{l}\text { Improves soil fertility and increase crop } \\
\text { production }\end{array}$ \\
\hline $\begin{array}{l}\text { mulching } \\
\text { (Section 3.1.5) }\end{array}$ & Not known & $\begin{array}{l}\text { Mostly in the } \\
\text { Sudan-Sahel }\end{array}$ & $\begin{array}{l}\text { Fertilizing the soil and attracts termites, } \\
\text { which dig holes into the soil with the effect of } \\
\text { increasing soil porosity and permeability }\end{array}$ \\
\hline
\end{tabular}

\subsubsection{Half-Moons}

Half-moons (Figure 4) were introduced by the environmental services of Burkina Faso in 1958 in the Yatenga region (Sudan-Sahel; Figure 1a), where most of the soil is found to be highly degraded. Farmers in this region did not largely adopt this technique because of the lack of training and money for implementation [70]. It is a semi-open mechanical structure with the shape of a half-circle that collects and holds runoff water (Figure 4) and improves soil infiltration. Thus, it contributes to recovering and restoring the fertility of the encrusted soil for agronomic and agroforestry purposes [58]. Half-moons are typically found in the Sahel, central North, and central plateau in Burkina Faso [71]. They are constructed by using a $2 \mathrm{~m}$ swiveling compass ray with a diameter of $4 \mathrm{~m}$ and a height of 0.15 to $0.25 \mathrm{~m}$. The recommended distance from the center of each semi-circle is $8 \mathrm{~m}$ apart, which is $4 \mathrm{~m}$ from each half-moon (Figure 4). The typical density is 312 half-moons per hectare [72]. Half-moons have a wider surface area than zai (c.f., Section 3.1.2) to store more water. Additionally, the growing of shrubs on the beds improves the crop yields on the farms and adequately maintains the half-moons [73]. 


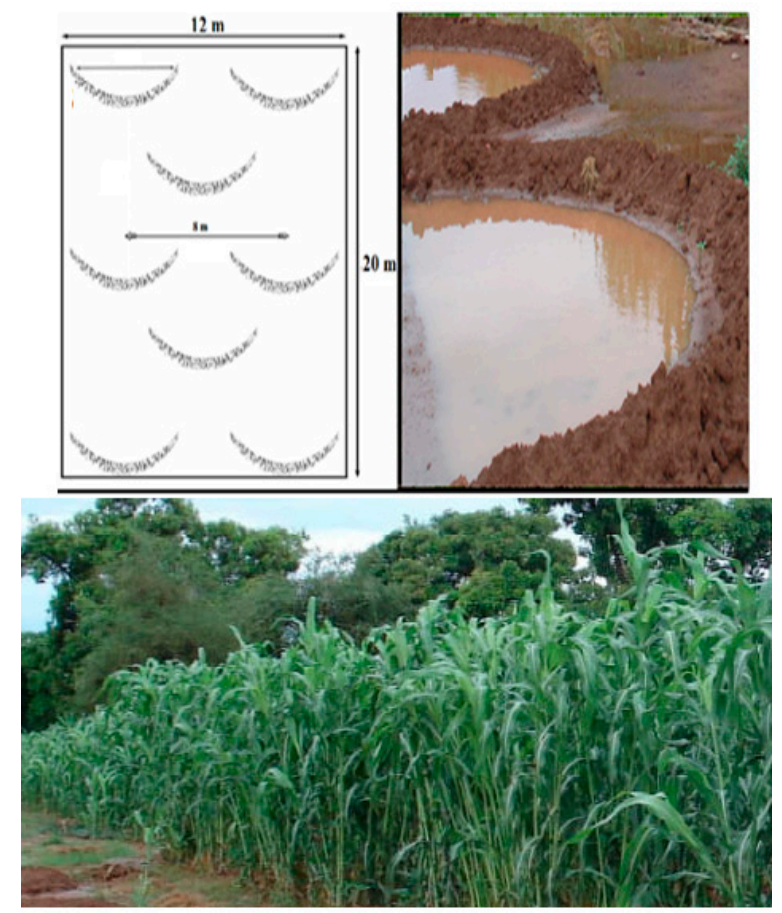

Figure 4. Schematic diagram [74] and photographs of half-moon implementation. The images were captured during a field campaign in August 2017 at Kongoussi in northern Burkina Faso.

\subsubsection{Improved Traditional Planting Pits (Zai)}

This SWCM is commonly applied in northern Burkina Faso (Figure 1), where the average annual rainfall is $562 \mathrm{~mm}$ and the soil is heavily encrusted [24]. Its implementation started in the 1980s (Table 2), when farmers in Ouahigouya city were in despair because of decreasing crop yields and increasing land degradation [75]. Zais are constructed by burying planting pits and filling them with organic matter during the dry season [76,77]. The implementation of zais is supposed to foster the retention of soil moisture and increase the available nutrients (Figure 5). The plant-pit is made of a diameter of 20 to $30 \mathrm{~cm}$ and an average depth of 10 to $15 \mathrm{~cm}$ [24,78] (Figure 5). This dimension varies, especially in the dry season when the pits have to be filled with mulch such as manure or crop residue [78]. The total number of zais at a farm side typically ranges between 12,000 and 15,000 per hectare [58]. They are normally buried during the dry season from November to May [79]. After digging the pits, organic matter is added and covered after the first rainfall. The manure placed in the hole attracts termites, which dig holes underground and thus facilitate the deeper infiltration of rainwater and runoff. The termites also bring nutrients from other deeper layers to the surface horizons and from the surface to the deeper layers [32].
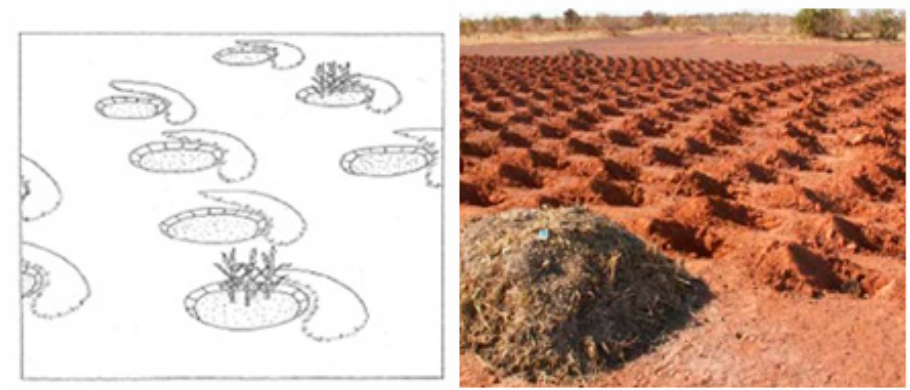

Figure 5. Schematic diagram and real picture of Zai. Source: [80]. 


\subsubsection{Stone Bunds}

The construction of stone bunds started in the late 1970s and early 1980s by the OXFAM-funded Agroforestry project in Yatenga, which was identified as having mostly highly degraded agricultural lands [32]. Between the 1970s and 1980s, only $2 \%$ of cultivated areas were equipped with stone bunds in order to improve water infiltration and to reduce the runoff potential, thus protecting the topsoil against erosive action $[75,81-83]$. The purpose was to develop water harvesting techniques to increase soil productivity and to eventually rehabilitate gullies, subsequently reducing the rate of land degradation [84]. It is one of the most efficient SWCM used by farmers in Burkina Faso [66], normally found in sub-Saharan West Africa [85]. Stone bunds are mainly used on gently sloping land where crops such as millet, groundnut, and rice are cultivated. Similar to farming bench terraces [86], stone bunds are formed by a contour-aligned dry-stone wall with heights ranging in average from 0.3 to $1 \mathrm{~m}$ (Figure 6; [24,32]). The dimensions may vary depending on the topographic situation in which they are constructed. The top of the backfill is covered with smaller rock fragments and rich soil that filter the sediments during heavy rains, as well as minimize overland flow [87]. However, small and dense branches of trees or grasses such as Andropogon gayanus, which have deeper roots, can be planted as walls to help prevent soil erosion (Figure 6c). These walls are referred to as "vegetalised" walls [88].
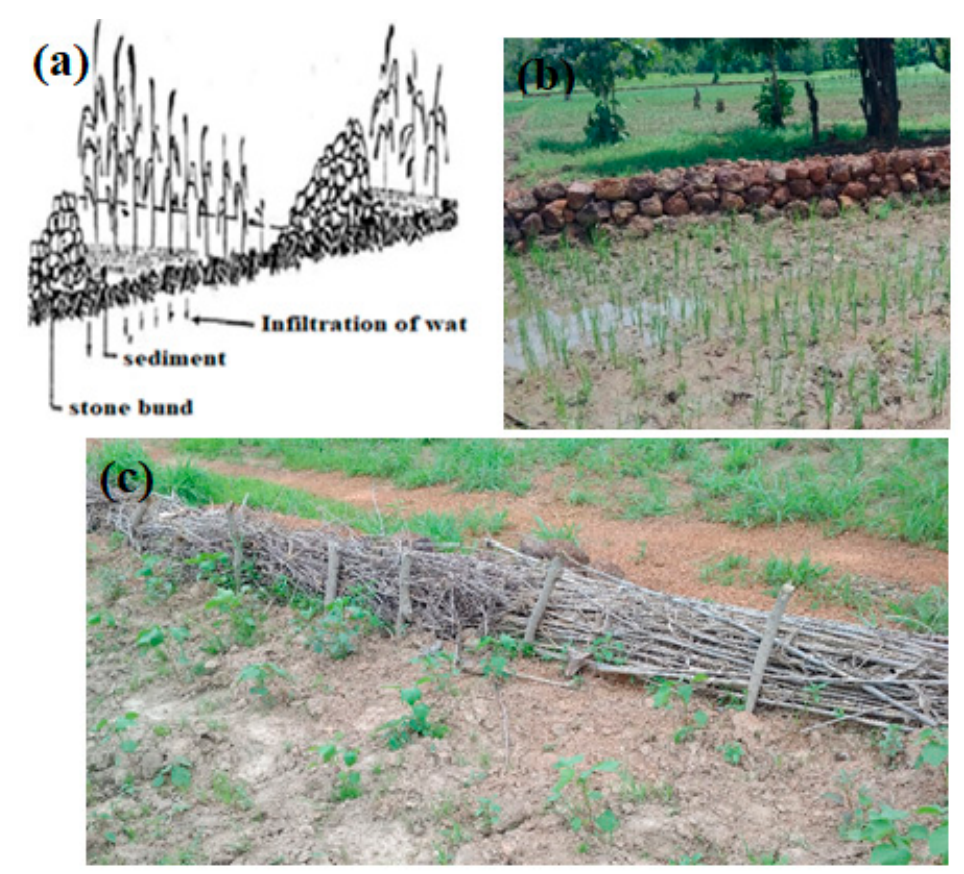

Figure 6. (a) Schematic diagram of a stone bund. (b) The images of stone bund implementation captured during a field campaign in July 2017 at Manzour in southwestern Burkina Faso, (c) Traditional bunds made of strips captured in the field in July 201 at Manzour. Source of (a): [24].

\subsubsection{Agroforestry}

The implementation of agroforestry as SWCM mainly began in 1970 (Table 2). Until recently, farmers continued with this measure due to the many benefits they got from certain fertilizing species, such as improvement in crop yields and generating income from the woods obtained from the farms. This method also helps in the preservation of a few useful tree species that are known to have some medicinal and economic value in the region [81]. For example, tree species such as Faidherbia albida (Figure 7) commonly used for agroforestry lose their leaves at the onset of the rainy season that also refers to the growing period of crops such as millet and sorghum, and thus crops get sufficient sunlight to grow. In the dry season, the deep tap roots of the trees absorb minerals, which are beyond the reach of other plants and store them in their fruits and leaves for future use [58,72,89]. A few of the tree species 
such as pigean pea (cajanus cajan) and the African oil bean (Pentaclethra macrophylla) [54] also enrich the topsoil and improve the crop yield by using the nitrogen they absorb from the atmosphere [89]. Leaves fallen also serve as mulch, providing nourishment during the wet season. The droppings of the animals feeding on the fallen leaves serve as manure. Farmers also use species such as young baobab (Adansonia digitata), shea (Vitellaria paradoxa), African locust bean (Parkia biglobosa), Indian lilac (Azadirachta indica), and apple-ring acacia (Faidherbia albida; Figure 7) in agroforestry for the purpose of soil regeneration and medical use [90]. A study by Belemvire [91] indicates that there is distinct improvement in the vegetation in the areas of northwestern Burkina Faso where agroforestry has been implemented.

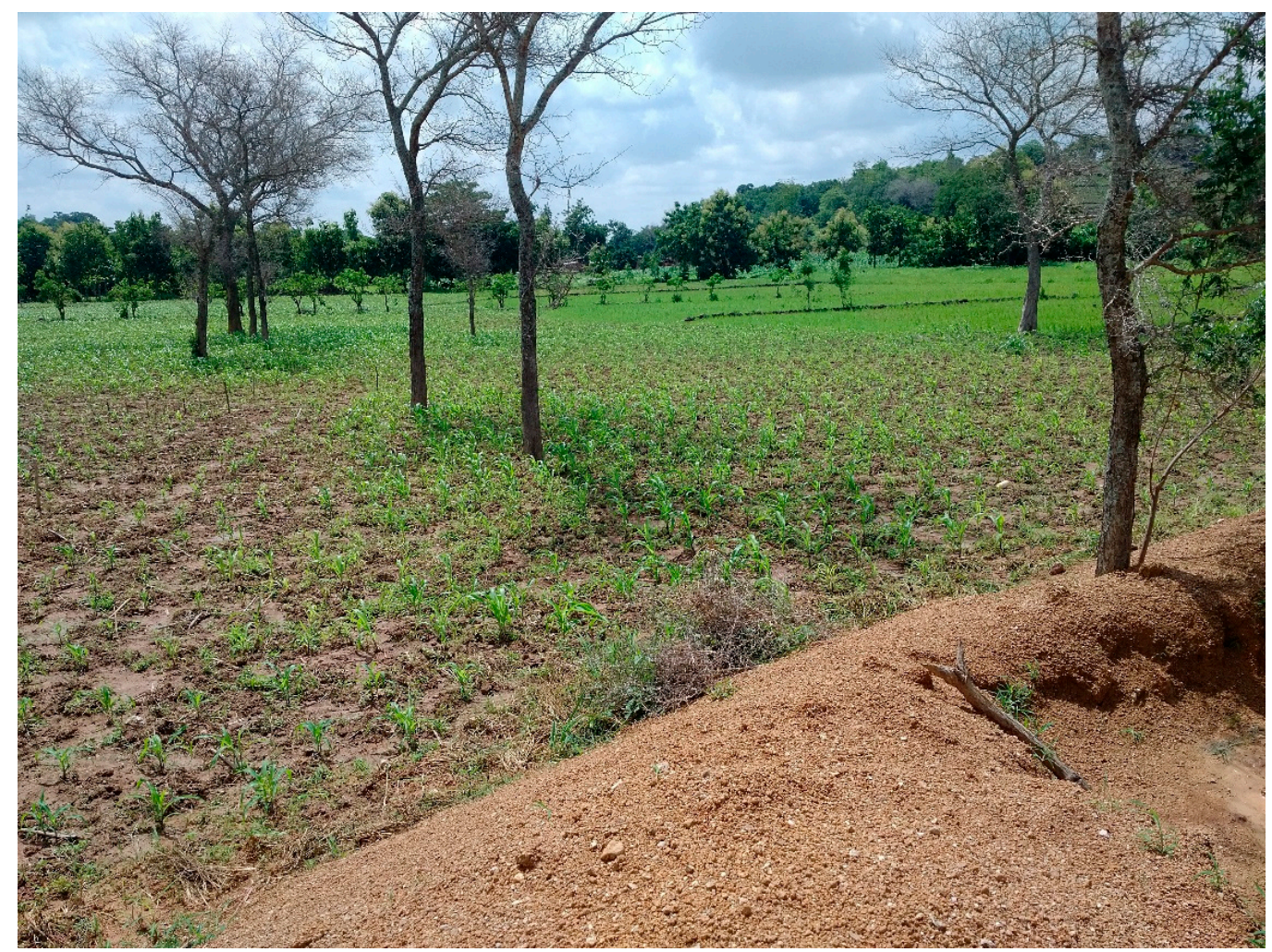

Figure 7. Agroforestry practice in Burkina Faso with Faidherbia albida. The images were taken in July 2017 at Batiara in southwestern Burkina Faso.

\subsubsection{Mulching}

This SWCM is widely practiced in all climate zones and on all soil types in Burkina Faso. It is implemented by covering the soil with a layer of dry grass (Figure 8) and residues of millet, maize, or sorghum of about a $2 \mathrm{~cm}$ thickness, which is equivalent to 3 to $6 \mathrm{tha}^{-1}$ [92]. Farmers use slices of grass, particularly from Loudetia togoensi, to cover topsoil, normally from April to May. In areas with a shortage of grass, farmers resort to the use of dried leaves from various trees, particularly Butyrospermum parkii. This initiative is common in the Sahel, the North, the central north, central plateau, central west, and central east of Burkina Faso (Figure 8a). In the semi-arid climate that is predominantly characterized by wind erosion [66,93], crop residues are used as mulch to protect the topsoil against the erosive force of wind. Local farmers also use this measure to protect the bare soil from becoming encrusted after harvest. Mulching is considered to rehabilitate the soil in the first year of implementation and afterwards eases the development of the vegetation in the subsequent year. 

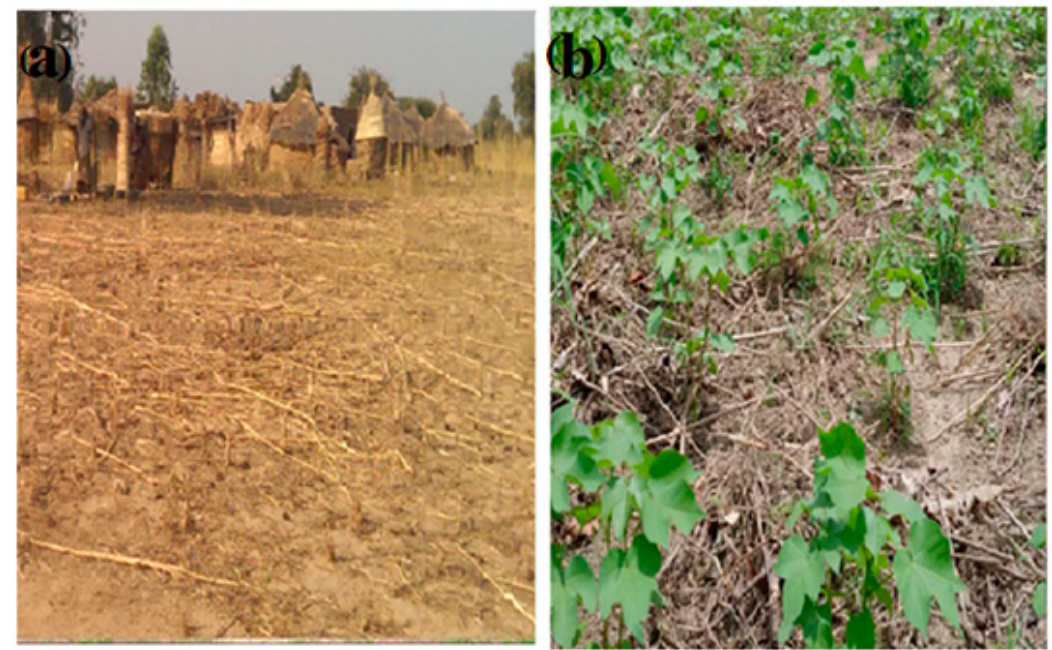

Figure 8. Mulching on farmlands in Burkina Faso. Image (a) was taken in Boulsa at December 2017 and image (b) was taken in Kongoussi at August 2017 in northern and northwestern Burkina Faso.

\section{Soil Erosion and Sediment Yield}

Soil erosion comprises the processes of particle detachment, transportation, and deposition of sediments by erosive agents such as water or wind [94]. The problems resulting from soil erosion can be both on-site and off-site, with the on-site effects triggering soil degradation (e.g., loss of water storage capacity and nutrient depletion) and constraining crop production [26]. The sediment yield can therefore be described as the amount of sediment reaching or passing a particular point at a given period of time [95]. In view of the above problem, soil conservation experts have developed various soil erosion models to investigate soil loss rates and sediment yields [94].

In Burkina Faso, few studies have estimated soil loss rates and sediment yields by water erosion from agricultural land at local and national scales [93] using models such as the Universal Soil Loss Equation (USLE) and its revised version RUSLE [96], WEPP [93], WaTEM/SEDEM [93], and EUROSEM [97]. However, each of those soil erosion models has its own limitation in terms of describing the complex physically-based erosion processes (e.g., sediment delivery and deposition). USLE basically emphasizes how climate plays a major role in soil erosion, with other secondary factors such as soil, topography, and vegetation cover also influencing soil erosion [98]. Though it is a commonly used model, it is also the most criticized because of the empirical-based equation as it limitation in simulating the sediment yield $[99,100]$. The physically-based soil erosion model WEPP is used for the spatial simulation of the temporal dynamic of soil and runoff processes at the hillslope and uses climate, slope, soil, and land management as input data [93]. The results from the WEPP model are influenced by the changes in the soil properties, particularly the soil texture, which has a significant effect on the soil bulk density, porosity, water retention, and hydraulic conductivity values [101,102]. The processed-based EUROSEM model is a dynamic model with processed-based equations able to simulate infiltration, sediment transport, erosion, and deposition at both runoff plots and field scales [97]. It is a complex model structure, which suffers from over parametrization, excess large data sets, and computational requirements [103]. Oostveen [96] used the USLE to estimate the amount of soil loss at the Tandjari catchment area in Burkina Faso. The results show an average annual soil loss rate of $1604 \mathrm{t} \mathrm{ha}^{-1}$ and annual gross sediment yield of 168,420 $\mathrm{t}$ for an area of 10,500 ha. These results were different from an average annual soil loss rate of 5 to $50 \mathrm{t} \mathrm{ha}^{-1}$ recorded at soil erosion hotspots at Dano and Wahable using the WEPP model [93]. The difference can be attributed to the topography or the physiographic location of the two sites and variation in the model or measuring technique used in predicting the soil loss and sediment yield of the various sites. Another explanation for the difference in values at various locations could be the soil structure, which has an influence on the susceptibility 
of soil erosion. Thus, soils with a higher percentage of stone coverage such as the one in the Dano catchment [93] are more resistant to erosion because of their potential in reducing the effect of splash, and thus particle detachment. On the other hand, the soils in the catchments Wahable and Tandjari are mostly fine particles, which are vulnerable to erosion [91,92]. The soil structure in these locations is not stable, leading to a high degree of soil detachment. Nonetheless, the SWCM carried out in these areas also have an effect on the soil erosion. For example, the stone bunds used in Dano and Tandjari reduced erosion more effectively than contour ploughing another SWCM at Wahable. However, these results support the assertion that SWCM effectively reduce the rate of soil loss, with stone bunds and mulching reducing soil loss by $95 \%$ and $45 \%$, respectively [93].

Other studies focused on the estimation of sediment yield from suspended discharge measurements in Burkina Faso [98,104]. For example, an annual sediment yield of 0.5 to $3.4 \mathrm{t} \mathrm{ha}^{-1}$ was estimated using the WaTEM/SEDEM model at a catchment scale with area sizes of 7.9 to $23.6 \mathrm{~km}^{2}$ [93]. These results are in agreement with those reported by Lamachère and Serpanie [105], who estimated an annual sediment yield of $0.4 \mathrm{tha}^{-1}$ for a catchment size of 4400 ha in the Gourga in the Yatenga Province of northern Burkina Faso with annual rainfall of $460 \mathrm{~mm}$. However, higher annual rates of 4 to $8 \mathrm{t} \mathrm{ha}^{-1}$ were observed in Katchari in Seno Province in the Sahel with annual rainfall of $512 \mathrm{~mm}$ with a smaller catchment size of 1.4 ha [106]. For larger catchments such as the white Volta and Kompienga with a size of 300,000 ha and 600,000 ha, respectively, each recorded an annual rate of $0.7 \mathrm{tha}^{-1}[107,108]$. Other larger catchments at Boulbi around Ouagadougou [109], Bogande of Gnagna Province, Tenado of Sanguie Province, and Borome of Bale Province of sizes of 102,000 ha, 92,000 ha, $38,000 \mathrm{ha}$, and 148,000 ha, respectively, estimated annual rates of $0.8 \mathrm{tha}^{-1}, 0.6 \mathrm{t} \mathrm{ha}^{-1}, 1.9 \mathrm{tha}^{-1}$, and $3.1 \mathrm{tha}^{-1}[109]$.

\section{Effectiveness of the Soil and Water Conservation Measures}

The influence of anthropogenic activities coupled with population growth have negatively affected the landscape. However, this trend is assumed to have changed in recent times in Burkina Faso due to the implementation of SWCM (Tables 1 and 2). These measures have immensely improved the soil structure, crop yield, ground water recharge, rainfall infiltration, and tree density $[65,110]$. Sawadogo et al. [81] proved that SWCM such as stone bunds (Figure 9), zais, and half-moons have led to a significant improvement in crop yield and increase in vegetative cover. Results from other studies indicate that stone bunds are able to increase the infiltration into soil by $15 \%$ on sandy to sandy-clay soils [105]. A reduction of runoff of $45 \%$ has been observed by Zougmoré et al. [110] after implementing stone bunds on farms. These results are in agreement with results achieved by Schmengler [93], who has applied a WEPP model simulation to show that stone lines reduce soil loss by $95 \%$. Zougmoré et al. [110] reported an increase in woody vegetation due to a $53 \%$ reduction in runoff through the implementation of stone bunds in the central plateau of Burkina Faso. These results support findings from other parts of Sub Sahelian Africa [111-113]. Sawadogo [114] highlighted the impact of stone bunds on crop yields (i.e., millet, sorghum, and maize). The results show yields of $0.79 \mathrm{tha}^{-1}$ for farms with stone bunds and $0.61 \mathrm{t} \mathrm{ha}^{-1}$ for farms without stone bunds. This refers to a distinct increase of approximately $30 \%$ when applying this certain SWCM. In view of the numerous positive effects of stone bunds, a few limitations hinder their implementation and maintenance by farmers. For instance, the implementation of stone bunds requires intensive labor and capital, which normally becomes a major challenge for the farmers [54].

Zai presents another effective option and a commonly used SWCM to rehabilitate degraded lands mostly called zipélé [66,75]. A study in northern Burkina Faso indicated over a 100\% increase in crop yields of sorghum, millet, and maize on farms where zais have been implemented [115]. The implementation of zais enables farmers to improve their crop yields by approximately 0.3 to $0.4 \mathrm{t} \mathrm{ha}^{-1}$ in years of minimal rainfall of about $560 \mathrm{~mm}$, and up to $1.5 \mathrm{tha}^{-1}$ in years of higher rainfall of about $650 \mathrm{~mm}$ [76]. The growth of young trees (agroforestry) in zai (combination of two SWCM) is assumed to support the regeneration of local species [116] and to mitigate environmental 
threats resulting from a wood shortage is some areas. According to Sawadogo [58], the success of zais has made them widely accepted and recognized across Burkina Faso and other Sahelian countries (e.g., Niger and Mali). However, because of the success achieved in the implementation of this SWCM, most families and households in Yatenga, Zondoma, Lorum, and Passore provinces in Sudan-Sahel (Figure 1) have adopted this in their farms, now covering an area of 30,000 to 60,000 ha in northwestern Burkina Faso [58].

Zougmoré et al. [110] reported that, half-moons positively affect crop yields, particularly in areas where manure and chemical fertilizers are applied. There was an increase in cereal production of 4.1\% annually between 1984 and 1986 [58], which were the early stages of half-moon implementation. The implementation of agroforestry as SWCM supports the restoration of the degraded soil through the planting of trees. Trees such as Shea and Néré trees used in agroforestry do not only help to restore the degraded soil, but also to generate a higher income for farmers by the selling of the fruits [117]. The fruits of Shea and Néré trees are used by most households for domestic purposes such as cooking since their fruits are rich in proteins and a variety of dietary minerals. Trees such as Mahogany, Cashew, Baobab, and Moringa used in agroforestry have both nutritional and medicinal values, and they also have opportunities to be engaged in carbon markets [117].

In general, implemented SWCM have helped in rehabilitating degraded lands and in achieving higher crop yields. This improvement has caused a drastic reduction in rural poverty by $50 \%$ and an increase in the rural population of 25\% between 1985 and 1996 [75,118]. In addition, the implementation of SWCM has greatly improved the groundwater, resulting in the rise of water tables in many villages, especially in areas with large stone bunds $[75,119]$.

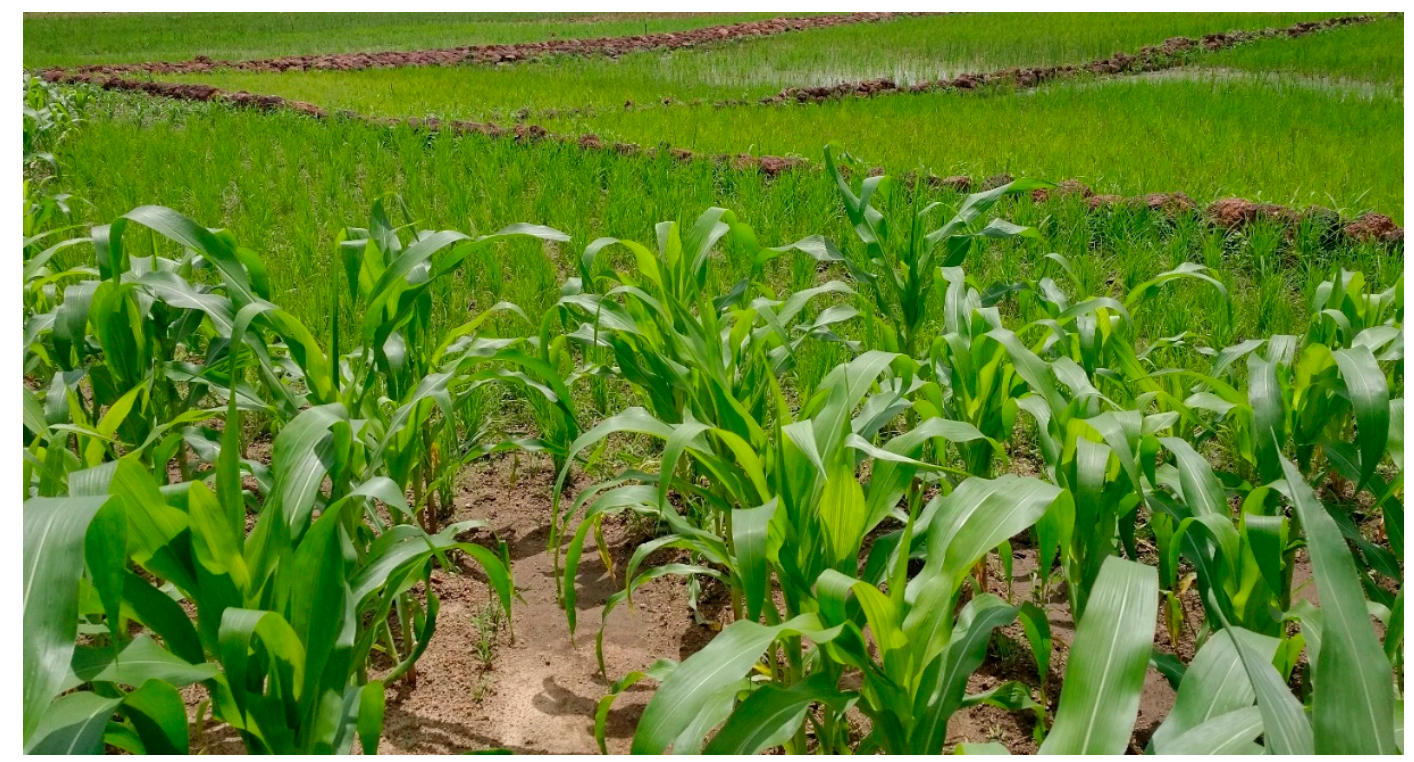

Figure 9. Rice and maize farm after the successful implementation of a stone bund at Lopal in southwestern Burkina Faso, captured during filed work in July 2017.

\section{Factors That Affect Soil and Water Conservation in Burkina Faso}

Soil erosion is still a major problem in many parts of Burkina Faso in terms of topsoil loss, sedimentation, and nutrient enrichment of surface waters. Soil erosion, coupled with the continuous disappearance of the vegetation, has resulted in the enormous decrease in soil thickness, as well as its nutrient holding capacity [120]. The situation could get worse under future climate change if not properly controlled with the right initiatives and measures. Most of SWCM, initiatives, and studies in Burkina Faso focus on the soil rehabilitation of agricultural lands, and pay less attention to the spatial dimension of soil erosion [93] and the conservation of natural vegetation [121,122]. Thus, the current SWCM and 
initiatives should be extended to address the conservation of natural vegetation. In addition, there is inadequate information on the coverage and extent of existing SWCM and initiatives. Also, the technical implementation and maintenance of SWCM requires much effort in terms of labor inputs and materials such as stones and wood $[115,123]$.

Therefore, factors constraining the implementation of the SWCM and initiatives should be addressed. This will make it easy for the farmers to implement them. One example is the replacement of organic manure with compost in its application with the stone bunds, zai, and half-moons when there is scarcity of organic manure. This can be achieved by empowering and developing the rural communities to produce quality compost and agricultural equipment that will facilitate the implementation of the technique and reduce the labor inputs. In addition, a participatory approach should be adopted in the planning and implementation stage of the SWCM. This can be achieved by involving the local farming in the integration of the local SWCM and modern scientific techniques.

\subsection{Migration of Work Force}

Many people in the country move from one region to another or migrate from the rural areas to urban areas to search for a job for a better living. The movement of the rural population to the urban areas creates problems in terms of urban development and leads to the over-exploitation of land in urban areas [123]. In recent times, migration has been perceived as a development pathway for less endowed areas covering large parts of Burkina Faso. Also, the migration of people is seen as a solution to poverty and social marginalization, whilst the global environmental change perceives migration as a solution to reduce vulnerability and increase livelihood security $[124,125]$. It has been recorded that seasonal internal migration has been in existence since the early colonial days [126], with the population growth of Ouagadougou and Bobo-Dioulasso, which are the major cities in Burkina Faso, increasing by 156\% and 101\%, respectively, between 1975 and 1985 [24]. Also, migrants (mostly the youth) from rural areas move towards the border West African countries like Ghana and Cote d'Ivoire in search of greener pastures [115]. The economic situation in these two West African countries is better than in Burkina Faso, so the migrants would rather go there to find jobs to improve their livelihood and remit some of the money to their relatives back home to support their income. This situation leads to the reduction of the working force in households [127] required for the implementation of SWCM since they are labor intensive.

\subsection{Cultivation of Cash Crops}

The major cash crops in Burkina Faso are cotton, cowpea, and sesame, mainly cultivated for export [128]. Because of the profit involved, farmers use various practices and modern techniques (e.g., mechanized soil preparation, improved seeds, chemical fertilizers) to improve crop yields [24]. The agricultural growth in Burkina Faso, which includes an increase in cash crop production, has resulted in huge environmental damage [20]. The various practices and techniques affect the soil structure, making it more vulnerable to erosion. Also, intensive agriculture and the application of chemical fertilizers can result in degradation of the soil, pollute the water resources [20], and destruct the micro-flora and micro-fauna, destroying the ecosystem balance. The need to promote new approaches to conserve natural resources in agriculture has been stressed in a report [129], the International Assessment of Agricultural Knowledge, as well as Science and Technology for Development [130]. In recent times, sustainable agriculture has become very crucial in the agricultural production system [20]. The practice of sustainable agriculture is used by farmers on their farms to rehabilitate the degraded soils. For example, the application of half-moons and organic fertilizer from livestock without using chemical fertilizer help farmers to improve their yield [131]. Improved SWCM to produce cash crops, staple foods, and crop diversification need much attention in the agricultural sector [55]. 


\subsection{Land Tenure Security}

Land tenure plays an important role in the adoption of SWCM. Ownership of the land encourages the farmers to invest in long-term improvement of the land [130-132]. However, the situation remains different when the ownership of land is expected to change with time [133]. The land chief is responsible for the religious and legal functions (i.e., the land chief performs all the sacrifices and also serves as the mediator to the gods) of the land according to the customary right of land tenure in the country. In view of this, individuals can only acquire land by a loan or lease system. Since the farmers are not the real owners of the land, they put lots of pressure on the land within a short time to generate the maximum crop yield and profit from their own land [83]. They also feel reluctant to implement SWCM, and their adoption are associated with land titling and ownership [134]. Moreover, the customary land tenure rights forbid the planting of trees an some sites [83]. Additionally, women who represent more than half of the agricultural workforce are not permitted to own land by the customary land tenure rights. This situation largely affects the implementation of SWCM [24]. It is not only in Burkina Faso that the long-term ownership of land affects the adoption of SWCM, but has also been recorded in countries such as Thailand [134], China [135], and the United States of America [136].

\section{Results and Discussion}

The spread of the SWCM began in the central plateau region in 1980s [137]. The total land area of adopted SWCM increased significantly in all the six regions from 1993 to 2006 (Figure 10). The East experienced the highest increase of change from 8672 ha in 1993 to 26,000 ha in 2006, representing about 200\% change within the period. The Sahel, North, and Central-North with less than $700 \mathrm{~mm}$ of annual rainfall have greater land masses due to adopting the SWCM in both 1993 and 2006. Such a large adoption of SWCM in an arid environment is purposely used to rehabilitate degraded lands [32]. Among the regions receiving less than $700 \mathrm{~mm}$ of rainfall a year, the Sahel region had the highest increase of change within the periods, from 23,000 ha to 62,000 ha (Figure 10). This represents $170 \%$ change within the period. In the East and Mouhoun regions where annual rainfall is between $700-900 \mathrm{~mm}$, the total land area adopted for SWCM was minimal. This can be attributed to SWCM being less productive in high rainfall areas where measures such as stone bunds and zai retain a lot of water, causing waterlogging $[89,137]$. The adoption of SWCM was estimated from the use of anti-erosion measures such as zai, stone bunds, half-moons, and agro-forestry in the agricultural fields [138].

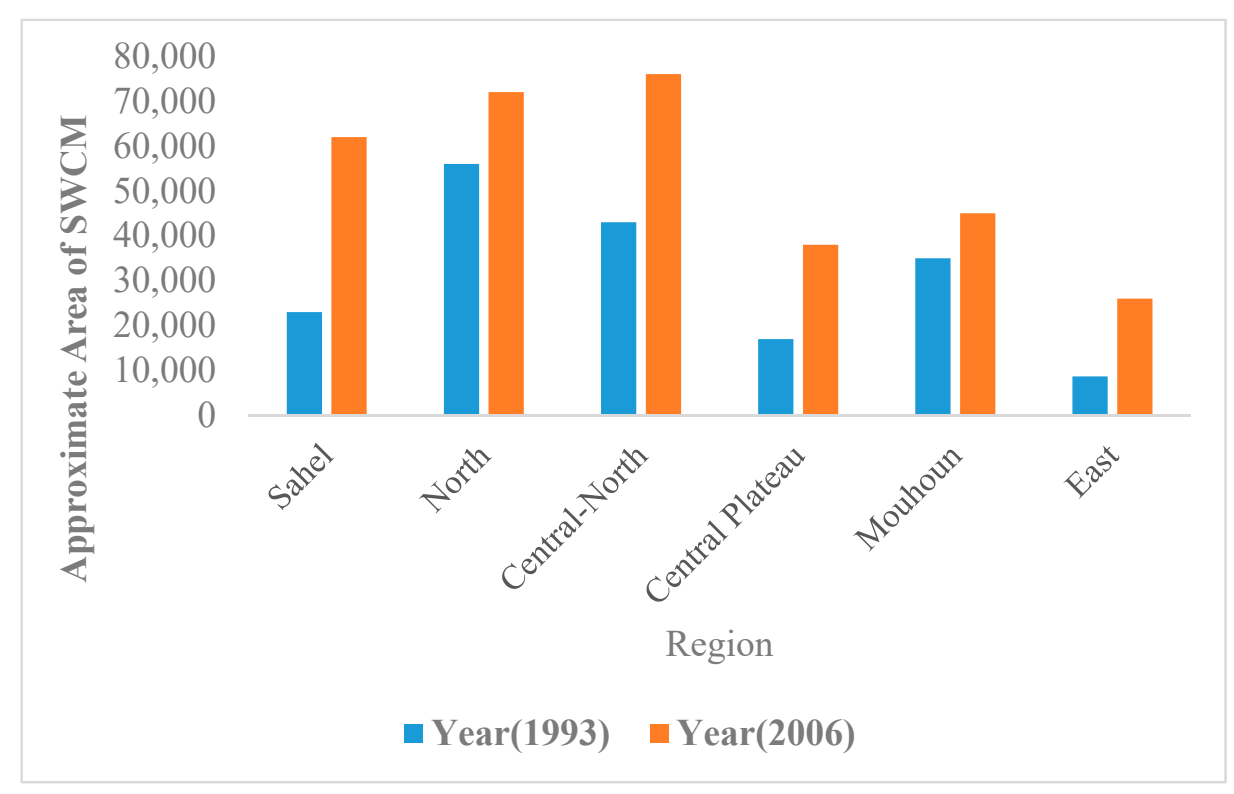

Figure 10. Total Area of Adopted SWCM by each region (1993-2000). Source: [138,139]. 
The results on yield relate to experimental field studies observing the positive effects of SWCM (zai, stone bunds, and half-moons) on sorghum in some parts of Burkina Faso (Table 3). These were accessed from different pieces of literature between 1980 to 2008. The results from the yield in each location clearly showed an increase in sorghum $\left(\mathrm{kg} \mathrm{ha}^{-1}\right)$ production within the periods. Zai and stone bunds are the most predominant SWCM across the regions and are mostly used in the Sahel and North, where most of the land is degraded ([45]; Table 3). The above results demonstrate that SWCM rehabilitate degraded lands, substantially increasing crop productivity [32].

Table 3. Impacts of some SWCM on sorghum yield in parts of Burkina Faso.

\begin{tabular}{|c|c|c|c|c|}
\hline Period & Type of SWCM & Town/Province/Region & Sorghum Yield $\left(\mathrm{kg} \mathrm{ha}^{-1}\right)$ & Reference \\
\hline $2004-2006$ & zai & Togou & $428-482$ & [137] \\
\hline 2006-2008 & zai & Leeba/Yatenga & $900-1200$ & [58] \\
\hline 2006-2008 & stone bund & Leeba & $700-1100$ & [58] \\
\hline 1984-2004 & half-moon & Northwest & $1400-2000$ & [58] \\
\hline $1986-$ & zai & - & 500-1000 & [138] \\
\hline 1982-1984 & stone bunds & North & Increment of 100 annually & [70] \\
\hline 1980-1988 & $\begin{array}{c}\text { zai/stone } \\
\text { bund/half-moon }\end{array}$ & North and Sahel & $600-700$ & [82] \\
\hline 1986-2000 & zai/half-moon & sahel & $1000-1500$ & {$[85,100]$} \\
\hline 1984-2001 & $\begin{array}{c}\text { zai/stone } \\
\text { bunds/half-moon }\end{array}$ & Centre-north/North & $611-793$ & {$[71,73]$} \\
\hline 1975-1985 & zai & Central plateau & $400-500$ & [118] \\
\hline
\end{tabular}

An analysis of results from other peer-reviewed publications showed that zais cover a total land area of 30,000 to 60,000 ha in northwestern Burkina Faso [58] and more than 200,000 ha of agricultural land in central Burkina Faso [32]. The adoption rate of zais in Yatenga province was between $49 \%$ and $60 \%$ [137]. This confirms that the adoption of zai by farmers in the province has been successful so far. Critchley and Graham [56] reported that stone bunds are applied on a total land area of 8000 ha in northern Burkina Faso and more than 176,093 of agricultural land in the region. It therefore covers $4.5 \%$ of the cultivated area in northern Burkina Faso. Additionally, stone bunds cover 32,990 and 20,302 ha of the total land area in the Centre-North and Centre-West, respectively. The total agricultural land covered by stone bunds in these regions is 284,708 and 392,951 ha, respectively [139]. It represents $11.6 \%$ and $5.2 \%$ of the cultivated area in each region [140]. Another study reviewed showed that agricultural lands increased from 8000 ha in 1990 to about 150,000 ha for each region in 2004 after adopting SWCM [140]. These results from the literature are the expected minimum since not all literature has been documented. In the central plateau, the introduction of SWCM between 1980 and 2002 improved the economic security and social stability in the region. Thus, with the inception of SWCM, farmers have achieved higher yields for both millet and sorghum. The average crop yields in 2002 ranged between 60 and $70 \mathrm{~kg} \mathrm{ha}^{-1}$, which is 50-60\% higher than the crop yields in 1980 [118]. Additionally, the annual rate of crop production increased to $4.1 \%$ between 1984 and 2002 following the implementation of SWCM [69].

However, with regard to the effects on soil loss and sediment yield, only a few studies are available to date, which mainly focus on local scales. The net erosion rates differ, depending on the model used in predicting the soil loss and sediment yield (c.f., Section 4). The USLE model produces a high soil loss rate and sediment yield in the Tandjari catchment site. However, the WEPP model predicted different soil loss rates with smaller values for both Dano and Wahable, with Wahable having a higher rate compared to the USLE model prediction. The reason for the difference may be attributed to the soil structure in both areas, which has a strong influence on the erodibility of the soil [101,102]. Thus, areas with a greater percentage of stone coverage like in Dano catchment, have a higher resistance to erosion because the stone cover reduces the detachment of the soil particles, causing less materials to be transported, and thus less runoff occurs [141]. On the contrary, the soil texture at Wahable is fine grained, which makes the soils very susceptible to particle detachment [142,143]. 


\section{Conclusions}

In Burkina Faso, most of the natural resources have been threatened by persistent land degradation resulting from climate change, improper farming practices, and pressure on land due to an increasing population and animal stocks. This situation called for the formulation of policies by development agencies (government, NGOs, projects) to curtail the menace. The policies have proved to be productive and beneficial in some regions of the country where the population has adopted the practice of SWCM to combat soil erosion.

It can therefore be concluded that the introduction of SWCM in Burkina Faso has improved agricultural productivity and food security, economic security, groundwater tables, tree regeneration, and biodiversity. It has also been efficient in reducing migration and poverty in the Sahel, especially in areas with a larger proportion of farmers and herders. These measures should be extended to other countries of the sub-Saharan Africa with a similar physio-graphic and socioeconomic situation, such as Niger and Mali, since they have proven to be workable initiatives to improve food security and crop yield while conserving the natural vegetation and establishing a more resilient climate change adaptation and mitigation means of agriculture. Additionally, the involvement of the local farmers makes them rely on their own resources and see the government and other agencies as secondary support. It is therefore essential for project organizers to recognize the importance of building on experience and improving on local SWC measures by promoting simple and low-cost technologies. The strengthening and re-organization of institutions is also necessary to help promote and oversee the successful implementation of SWCM.

Author Contributions: C.N. has designed the concept of the manuscript supervised by L.K.A. and M.T. S.S.-S. and B.J.-B.Z. contributed content-related and regional expertise. All authors contributed to the results, related discussions, and manuscript writing.

Acknowledgments: The authors want to acknowledge the provision of a scholarship and funding from the Federal Ministry of Education and Research (BMBF) and West African Science Centre on Climate Change and Adapted Land Use (WASCAL). We also want to thank the Martin Baumgart and Projet Adaptation au Changement Climatique (EKF) for giving us the opportunity to work with them during the field campaign. Our sincere thanks also go to the reviewers for their critical and constructive comments.

Conflicts of Interest: The authors declare no conflict of interest.

\section{References}

1. Lanckriet, S.; Derudder, B.; Naudts, J.; Bauer, H.; Deckers, J.; Haile, M.; Nyssen, J.A. Political Ecology Perspective of Land Degradation in the North Ethiopian Highlands. Land Degrad. Dev. 2015, 26, 521-530. [CrossRef]

2. United Nations. Millennium Development Goal; United Nations: New York, NY, USA, 2015.

3. Oldeman, I. Soil Resilience and Sustainable Land Use; ISRIC: Wageningen, The Netherlands, 1994; pp. 19-36.

4. ICOLD. Sedimentation and Sustainable Use of Reservoirs and River Systems; Draft Icold Bulletin; International Commission on Large Dams (ICOLD): Paris, France, 2009.

5. FAO. The State of the World's Land and Water Resources for Food and Agriculture (SOLAW): Managing Systems at Risk; Food and Agricultural Organization of the United Nations Report: Rome, Italy, 2011.

6. IAEA (International Atomic Energy Agency). Guidelines for Using Fallout Radionuclides to Assess Erosion and Effectiveness of Soil Conservation Strategies; IAEA: Vienna, Austria, 2014.

7. Collins, A.L.; Walling, D.E.; Sichingabula, H.; Leeks, G.J. Using 137Cs measurements to quantify soil erosion and redistribution rates for areas under different land use in the Upper Kaleya River basin, southern Zambia. Geoderma 2001, 104, 299-323. [CrossRef]

8. Morgan, R.P. Soil Erosion and Conservation, 3rd ed.; Wiley: Oxford, UK, 2005; ISBN 139781405117814.

9. Okou, F.A.Y.; Tente, B.; Bachmann, Y.; Sinsin, B. Regional erosion risk mapping for decision support: A case study from West Africa. Land Use Policy 2016, 56, 27-37. [CrossRef]

10. Smith, P.; House, J.I.; Bustamante, M.; Sobocká, J.; Harper, R.; Pan, G.; West, P.C.; Clark, J.M.; Adhya, T.; Rumpel, C.; et al. Global change pressures on soils from land use and management. Glob. Chang. Biol. 2016, 22, 1008-1028. [CrossRef] [PubMed] 
11. Agboola, A.A.; Aiyelari, E.A. Land degradation and soil fertility decline in Africa. Afr. Soils 2000, 31, 35-53.

12. Bationo, A.; Kihara, J.; Vanlauwe, B.W.; Kimetu, J. Soil organic carbon dynamics, functions and management in West African agro-ecosystems. Agric. Syst. 2007, 94, 13-25. [CrossRef]

13. Sivakumar, M.V.K. Interactions between climate and desertification. Agric. For. Meteorol. 2007, 142, $143-155$. [CrossRef]

14. Cobo, J.G.; Dercon, G.; Cadisch, G. Nutrient balances in African land use systems across different spatial scales: A review of approaches, challenges and progress. Agric. Ecosyst. Environ. 2010, 136, 1-15. [CrossRef]

15. Lal, R. Soil degradation by erosion. Land Degrad. Dev. 2001, 12, 519-539. [CrossRef]

16. Toy, T.J.; Foster, G.R.; Renard, K.G. Soil Erosion: Processes, Prediction, Measurement, and Control; John Wiley \& Sons: New York, NY, USA, 2002; ISBN 071383694.

17. United Nations Environmental Programme (UNEP). Global Environment Outlook 4: UNEP; UNEP: Valletta, Malta, 2012.

18. IRIN. Burkina Faso: Population Growth Outstrips Economic Gains. 2009. Available online: http:/ /www. irinnews.org/report/82501/ (accessed on 8 March 2018).

19. World Population Review. Burkina Faso Population. 2018. Available online: http://worldpopulationreview. com/countries/burkina-faso-population/ (accessed on 8 March 2018).

20. Lenhardt, A.; Glennie, J.; Intscher, N.; Ali, A.; Morin, G. A Greener Burkina: Sustainable Farming Techniques, Land Reclamation and Improved Livelihoods; The Overseas Development Institute: London, UK, 2014.

21. Green, J. The Effects of Population Growth on Land Use; American Society of Landscape Architects: Washington, DC, USA, 2009.

22. Forkuor, G.; Conrad, C.; Thiel, M.; Ullmann, T.; Zoungrana, E. Integration of optical and Synthetic Aperture Radar imagery for improving crop mapping in Northwestern Benin, West Africa. Remote Sens. 2014, 6, 6472-6499. [CrossRef]

23. Zoungrana, B.J.-B.; Conrad, C.; Thiel, M.; Amekudzi, L.K.; Da, E. MODIS NDVI trends and fractional land cover change for improved assessments of vegetation degradation in Burkina Faso, West Africa. J. Arid Environ. 2018, 153, 66-75. [CrossRef]

24. Bandre, P. Soil and Water Conservation Techniques in Burkina Faso; Oakland Institute: Oakland, CA, USA, 2002; pp. 30-31.

25. Szabo, S. Urbanisation and Food Insecurity Risks: Assessing the Role of Human Development. Oxf. Dev. Stud. 2015, 44, 28-48. [CrossRef]

26. Pimentel, D. Soil erosion: A food and environmental threat. Environ. Dev. Sustain. 2006, 8, 119-137. [CrossRef]

27. Lal, R. Enhancing crop yield in the developing countries through restoration of soil organic carbon pool in agricultural lands. Land Degrad. Dev. 2006, 17, 197-209. [CrossRef]

28. Pimentel, D.; Satkiewicz, P. Soil Erosion Threatens Food Production. Agriculture 2013, 3, 443-463. [CrossRef]

29. Ritsema, C.J.; Van Lynden, G.W.J.; Jetten, V.G.; de Jong, S.M. Degradation. In Encyclopedia of Soils in the Environment, 1st ed.; Hillel, D., Rosenzweig, C., Powlson, D., Scow, K., Singer, M., Sparks, D., Eds.; Academic Press: Cambridge, MA, USA, 2005; pp. 370-377.

30. Dialla, B.E. The Adoption of Soil Conservation Practices in Burkina Faso: The Role of Indigenous Knowledge, Social Structure and Institutional Support. Ph.D. Thesis, Iowa State University, Ames, IA, USA, 1992.

31. Forkuor, G.; Hounkpatin, O.K.L.; Welp, G.; Thiel, M. High Resolution Mapping of Soil Properties Using Remote Sensing Variables in South-West Burkina Faso: A Comparison of Machine Learning and Multiple Linear Regression Models. PLoS ONE 2017, 12, e0170478. [CrossRef] [PubMed]

32. Reij, C.; Tappan, G.; Smale, M. Re-greening the Sahel: Farmer-led innovation in Burkina Faso and Niger. In Millions Fed: Proven Successes in Agricultural Development; Spielman, D.J., Pandya-Lorchpp, R., Eds.; International Food Policy Research Institute: Washington, DC, USA, 2009; pp. 53-58.

33. Youngers, S.D.; Bonkougou, E.G. Burkina Faso: The Project Agro-Forestier, a case study of agricultural research and extension. In Successful Development in Africa: Case Studies of Projects, Programs, and Policies; EDI Development Policy Case Series; Analytical Case Studies No. 1; The World Bank: Washington, DC, USA, 1989.

34. Nyssen, J.; Clymans, W.; Poesen, J.; Vandescasteele, I.; De Baets, S.; Haregeweyn, N.; Naudts, J.; Hadera, A.; Moeyersons, J. How soil conservation affects the catchment sediment budget: A comprehensive study in the north Ethiopian highlands. Earth Surf. Process. Landf. 2009, 34, 1216-1233. [CrossRef] 
35. Taye, G.; Poesen, J.; Wesemael, B.; Vanmaercke, M.; Teka, D.; Deckers, J.; Haregeweyn, N. Effects of land use, slope gradient, and soil and water conservation structures on runoff and soil loss in semi-arid Northern Ethiopia. Phys. Geogr. 2013, 34, 236-259. [CrossRef]

36. Descheemaeker, K.; Nyssen, J.; Rossi, J.; Poesen, J.; Haile, M.; Raes, D.; Muys, B.; Moeyersons, J.; Deckers, S. Sediment deposition and pedogenesis in exclosures in the Tigray Highlands, Ethiopia. Geoderma 2006, 132, 291-314. [CrossRef]

37. Haregeweyn, N.; Poesen, J.; Deckers, J.; Nyssen, J.; Haile, M.; Govers, G.; Verstraeten, G.; Moeyersons, J. Sediment-bound nutrient export and associated costs from micro-dam catchments of Northern Ethiopia. Land Degrad. Dev. 2008, 19, 136-152. [CrossRef]

38. Amsalu, A.; de Graaff, J. Farmers' views of soil erosion problems and their conservation knowledge at Beressa watershed, central highlands of Ethiopia. Agric. Hum. Values 2006, 23, 99-108. [CrossRef]

39. Tefera, B.; Sterk, G. Land management, erosion problems and soil and water conservation in Fincha'a watershed, western Ethiopia. Land Use Policy 2010, 27, 1027-1037. [CrossRef]

40. Burkina Faso INDC. Intended Nationally Determined Contribution (INDC) in Burkina Faso. 2015. Available online: http:/ / www4.unfccc.int/ndcregistry/PublishedDocuments/BurkinaFasoFirst/INDCBurkina_ENG. version_finale.pdf (accessed on 23 February 2018).

41. Hiernaux, P.; Ayantunde, A.; Kalilou, A.; Mougin, E.; Gérard, B.; Baup, F.; Grippa, M. Trends in produ ctivity of crops, fallow and rangelands in Southwest Niger: Impact of land use, management and variable rainfall. J. Hydrol. 2009, 375, 65-77. [CrossRef]

42. Brandt, M.; Hiernaux, P.; Tagesson, T.; Verger, A.; Rasmussen, K.; Diouf, A.A.; Mbow, C.; Mougin, E.; Fensholt, R. Woody plant cover estimation in drylands from Earth Observation based seasonal metrics. Remote Sens. Environ. 2016, 172, 28-38. [CrossRef]

43. Boffa, J.M. Agroforestry Parkland in Sub-Saharan Africa: FAO Conservation Guide 34; Food and Agriculture Organization of the United Nations: Rome, Italy, 1999.

44. Callo-Concha, D.; Gaiser, T.; Webber, H.; Tischbein, B.; Müller, M.; Ewert, F. Farming in the West African Sudan Savanna: Insights in the context of climate change. Afr. J. Agric. Res. 2013, 8, 4693-4705. [CrossRef]

45. Bossard, L. Regional Atlas on West Africa; OECD Publishing: Paris, France, 2009.

46. Knauer, K.; Gessner, U.; Fensholt, R.; Forkuor, G.; Kuenzer, C. Monitoring agricultural expansion in Burkina Faso over 14 years with $30 \mathrm{~m}$ resolution time series: The role of population growth and implications for the environment. Remote Sens. 2017, 9, 132. [CrossRef]

47. Hijmans, R.J.; Cameron, S.E.; Parra, J.L.; Jones, P.G.; Jarvis, A. Very high resolution interpolated climate surfaces for global land areas. Int. J. Clim. 2005, 25, 1965-1978. [CrossRef]

48. Jenness, J.; Dooley, J. GIS Based Tools for Inland Acquatic Resource Management: Concept and Application Case Studies; CIFA Technical Paper 33/1; International Food Policy Research Institute: Washington, DC, USA, 2007.

49. FAO. World Reference Base for Soil Resources: International Soil Classification System for Naming and Creating Legends for Soil Maps; FAO: Rome, Italy, 2015.

50. Ministry of Agriculture. Climatic and Agro-ecological Zones of Burkina Faso; Ministry of Agriculture: Ouagadougou, Burkina Faso, 2017.

51. Meterological Agency. Rainfall and Temperature Data of Burkina Faso; Meterological Agency: Ouagadougou, Burkina Faso, 2018.

52. WOCAT. Where the Land Is Greener: Case Studies and Analysis of Soil and Water Conservation Initiatives Worldwide; CTA: Wageningen, The Netherlands, 2007.

53. Critchley, W.R.S.; Reij, C.; Willcoks, T.J. Indigenous soil and water conservation: A Review of the state of knowledge and prospects for building on traditions. Land Degrad. Dev. 1994, 5, 293-314. [CrossRef]

54. Pretty, J.; Shaw, P. Making soil and water conservation sustainable: From coercion and control to partnerships and participation. Land Degrad. Dev. 1997, 8, 39-58. [CrossRef]

55. Reij, C. Indigenous Soil and Water Conservation in Africa; IIED Gatekeeper Series No. 27; IIED: London, UK, 1991.

56. Critchley, W.R.S.; Graham, O. Looking after Our Land. New Approaches to Soil and Water Conservation in Dryland Africa; Oxfam Publication: Oxford, UK, 1991.

57. Pacey, A.; Cullis, A. Rainwater Harvesting; Intermediate Technology Publications: London, UK, 1986.

58. Sawadogo, H. Using soil and water conservation techniques to rehabilitate degraded lands in Northwestern Burkina Faso. Int. J. Agric. Sustain. 2011, 9, 120-128. [CrossRef] 
59. Dabiré, F. Revolutionary Conservation: Villages Successfully Use Stones against Erosion. West Africa, September 1989; 11-17.

60. Reij, C. Soil and Water Conservation in Sub-Saharan Africa: The Need for a Bottom-Up Approach; IFAD: Rome, Italy, 1987.

61. Warren, D.M.; Cashman, K. Indigenous Knowledge for Agriculture and Rural Development; Sustainable Agriculture Programme, International Institute for Environment and Development (IIED): London, UK, 1988.

62. Cashman, K. Agricultural research centers and indigenous knowledge systems: In a worldwide perspective: Where do we go from here? In Indigenous Knowledge Systems: Implications for Agriculture and International; Warren, D.M., Slikkerveer, L.J., Titilola, S.O., Eds.; Studies in TSC Series, No. 11; TSC Program; AGRIS: Rome, Italy, 1989.

63. Richards, P. Indigenous agricultural knowledge and international agricultural research. In Indigenous Knowledge Systems for Agriculture and Rural Development: The CIKARD Inaugural Lectures (Studies in TSC Series, No. 13); Richards, P., Slikkerveer, L.J., Phillips, A.O., Eds.; Iowa State University: Ames, IA, USA, 1989; pp. 4-18.

64. Gladwin, C. Ethnographic Decision Tree Modeling: Qualitative Research Methods Series; SAGE Publications: London, UK, 1989.

65. Sawadogo, S.; Ouattara, K.; Ouédraogo, I.; Balima, M.; Sawadogo, M.; Traoré, S.; Gowing, J. Burkina Faso: Cradle of Farm Scale Technologies. In Water Harvesting in Sub-Saharan Africa; Taylor \& Francis: Milton Park, Didcot, UK, 2012.

66. Zougmoré, R.; Jalloh, A.; Tioro, A. Climate-smart soil water and nutrient management options in semiarid West Africa: A review of evidence and analysis of stone bunds and zaï techniques. Agric. Food. Secur. 2014, 3 , 16. [CrossRef]

67. Serme, I.; Ouattara, K.; Logah, V.; Taonda, J.B.; Pale, S.; Quansah, C.; Abaidoo, C.R. Impact of tillage and fertility management options on selected soil physical properties and sorghum yield. Int. J. Biol. Chem. Sci. 2015, 9, 1154-1170. [CrossRef]

68. Sawadogo, H.; Bock, L.; Lacroix, D.; Zombre, N.P. Restauration des potentialites de sols dégradés à l'aide du zar et du compost dans le Yatenga (Burkina Faso). Biotechnol. Agron. Soc. Environ. 2008, 12, $279-290$. (In French)

69. Sawadogo, H. Fertilisation Organique et Phosphate'e en Systeme de Culture za1, en Milieu Soudano Sahelien du Burkina Faso. Ph.D. Thesis, Faculte Universitaire des Sciences Agronomiques de Gembloux, Gembloux, Belgium, 2006. (In French)

70. Zougmoré, R.; Kaboré, D.; Lowenberg-Deboer, J. Optimal Spacing of Soil Conservation Barriers: Example of Rock Bunds in Burkina Faso. Agric. J. 2000, 92, 361-368.

71. Zougmoré, R.B. Integrated Water and Nutrient Management for Sorghum Production in Semi-Arid Burkina Faso. Ph.D. Thesis, Wageningen University, Wageningen, The Netherlands, 2003.

72. Zougmoré, R.; Mando, A.; Ringersma, J.; Stroosnijder, L. Effect of combined water and nutrient management on runoff and soil erosion in semi-arid Burkina Faso. Soil Use Manag. 2003, 19, 257-264. [CrossRef]

73. Zougmoré, R.; Zida, Z.; Kambou, N.F. Réhabilitation des sols dégradés: Rôles des amendements dans le succès des techniques de demi-lune et de Zaï au Sahel. Bull. Rés. Eros. 1999, 19, 536-550. (In French)

74. CPP. Burkina Faso-Sub-Programme of the Nothern Region under Partnership Programme for Sustainable Land Management. 2007. Available online: https://www.thegef.org/project/cpp-burkina-faso-subprogramme-northern-region-under-partnership-programme-sustainable-land (accessed on 13 April 2018).

75. Reij, C.; Tappan, G.; Belemviré, A. Changing land management practices and vegetation in the Central Plateau of Burkina Faso (1968-2002). J. Arid Environ. 2005, 63, 642-659. [CrossRef]

76. Kaboré, P.D.; Reij, C. The Emergence and Spreading of an Improved Traditional Soil and Water Conservation in Burkina Faso; Environment and Production Technology Division Discussion Paper; International Food Policy Research Institute: Washington, DC, USA, 2004.

77. Ouedraogo, A.; Sawadogo, H. Three Models of Extension by Farmer Innovators in Burkina Faso. In Farmer Innovation in Africa: A Source of Inspiration for Agricultural Development; Reij, C., Waters-Bayer, A., Eds.; Earthscan: London, UK, 2001; pp. 213-217.

78. Motis, T.; D'Aiuto, C.; Lingbeek, B. Zai Pit System; ECHO Technical Note 78; ECHO: North Fort Myers, FL, USA, 2013. 
79. Ouédraogo, M.; Kaboré, V. The "zai": A traditional technique for the rehabilitation of degraded land in the Yatenga, Burkina Faso. In Sustainig the Soil. Indigenous Soil and Water Conservation in Africa; Reij, C., Scoones, I., Toulmin, C., Eds.; IIED: London, UK, 1996; pp. 80-92.

80. Botoni, E.; Reij, C. Silent Transformation of Environment and Production Systems in the Sahel: Impacts of Public and Private Investments in Natural Resource Management; IFPRI Discussion Paper; CILSS: Ouagadougou, Burkina Faso, 2009; p. 43.

81. Sawadogo, H.; Hien, F.; Sohoro, A.; Kambou, F. Pits for trees: How farmers in semi-arid Burkina Faso increase and diversify plant biomas. In Farmer Innovation in Africa: A Source of Inspiration for Agricultural Development; Reij, C., Waters-Bayer, A., Eds.; Earthscan: London, UK, 2001.

82. Maatman, A.; Sawadogo, H.; Scheigman, C.; Ouedraogo, A. Application of rock bunds and Zai in the North-West region of Burkina Faso: Study of its impact on household level by using linear programing model. Neth. J. Agric. Sci. 1998, 46, 123-136.

83. Kessler, J.J.; Geerling, C. Profile Environmental du Burkina Faso; Agricultural University of Wageningen, Department of Nature Conservation: Wageningen, The Netherlands, 1994.

84. Wright, P. La conservation des eaux et des sols par les paysans. In Technologies Appropriees Pour les Paysans des Zones Semi-Arides de L'afrique de l'Ouest; Ohm, W., Ed.; Purdue University: West Lafayette, IN, USA, 1985. (In French)

85. Zougmoré, R.; Mando, A.; Stroosnijder, L. Rôle des nutriments dans le succès des techniques de conservation des eaux et des sols (cordons pierreux, bandes enherbées, zaï et demi-lunes) au Burkina Faso. Sécheresse 2004, 15, 41-48. (In French)

86. Schönbrodt-Stitt, S.; Behrens, T.; Schmidt, K.; Shi, X.; Scholten, T. Degradation of cultivated bench terraces in the Three Gorges Area: Field mapping and data mapping. Ecol. Indic. 2013, 34, 478-493. [CrossRef]

87. Nyssen, J.; Poessen, J.; Gebremichael, D.; Vancampenhout, K.; D’aes, M.; Yihdego, G.; Govers, G.; Leirs, H.; Moeyersons, J.; Naudts, J.; et al. Interdisciplinary on-site evaluation of stone bunds to control soil erosion on cropland in northern Ethiopia. Soil Tillage Res. 2007, 94, 151-163. [CrossRef]

88. Sabet, Y. Techniques pour la Conservation des Eaux de Ruissellement et la Restauration des sols au Niger; Forestry Project IDA/FAC/CCCE; Ministry of Agriculture and the Environment: Niamey, Niger, 1989; p. 57. (In French)

89. Zougmoré, R.; Mando, A.; Stroosnijder, L. Soil nutrient and sediment loss as affected by erosion barriers and nutrient source in semi-arid Burkina Faso. Arid Land Res. Manag. 2009, 23, 85-101. [CrossRef]

90. Zoungrana, J.B. Vegetation Dynamics in the Southwest of Burkina Faso in Response to Rainfall Variability and Land Use. Ph.D. Thesis, Kwame Nkrumah University of Science and Technology, Kumasi, Ghana, 2016.

91. Belemvire, A. Impact de la Conservation de l'Eau et des Sols sur la Regeneration Naturelle Assistée. Developpement Rural et Environment au Burkina Faso: La Rehbilitation de la Capacite des Terroirs sur la Partie Nord du Plateau Central Entre 1980 et 2000; Rapport de Travail No. 1; Conseil National pour la Gestion de I' Environment: Ouagadougou, Burkina Faso, 2003. (In French)

92. Mando, A.; Brussaard, L.; Stroonsnijder, L. Termites and mulch mediated rehabilitation of vegetation on crusted soil in West Africa. Rest. Ecol. 1999, 7, 33-41. [CrossRef]

93. Schmengler, A.C. Modeling Soil Erosion and Reservoir Sedimentation at Hillslope and Catchment Scale in Semi-Arid Burkina Faso. Ph.D. Thesis, University of Bonn, Bonn, Germany, 2011.

94. Hajigholizadeh, M.; Melesse, A.M.; Fuentes, H. Erosion and Sediment Transport Modelling in Shallow Waters: A Review on Approaches, Models and Applications. Int. J. Environ. Res. Public Health 2018, 15, 518. [CrossRef] [PubMed]

95. White, S. Sediment yield prediction and modelling. Hydrol. Process. 2005, 19, 3053-3057. [CrossRef]

96. Oostveen, N. Modelling Soil Erosion and Reservoir Sedimentation Using USLE Case Study of The Tandjari Catchment in the Gourma Region. Bachelor's Thesis, Van Hall Larenstein University of Applied Sciences, Velp, The Netherlands, 2017.

97. Visser, S.M.; Sterk, G.; Karssenberg, D. Modelling water erosion in the Sahel: Application of a physically based soil erosion model in a gentle sloping environment. Earth Surf. Process. Landf. 2005, 30, 1547-1566. [CrossRef]

98. De Hipt, F.O.; Diekkrüger, B.; Steup, G.; Yira, Y.; Hoffmann, T.; Rode, M. Applying SHETRAN in a tropical west African catchment (Dano, Burkina Faso)—Calibration, validation, uncertainty assessment. Water 2017, 9, 101. [CrossRef] 
99. Kinnel, P.I. Event soil loss, runoff and the Universal Soil Loss Equation family of models: A review. J. Hydrol. 2010, 385, 384-397. [CrossRef]

100. Boardman, J. Soil erosion science: Reflections on the limitations of current approaches. Catena 2006, 68, 73-86. [CrossRef]

101. Flanagan, D.C.; Livingstone, S.J. Water Erosion Prediction Project: User Summary; NSERL Report No. 11; USDA-ARS National Soil Erosion Research Laboratory: West Lafayette, IN, USA, 1995.

102. Alberts, E.E.; Nearing, M.A.; Weltz, M.A.; Risse, L.M.; Pierson, F.B.; Zhang, X.C.; Laflen, J.M.; Simanton, J.J. Soil component. In USDA-Water Erosion Prediction Project (WEPP). Hillslope Profile and Watershed Model Documentation; Flanagan, D.C., Nearing, M.A., Eds.; NSERL Report No. 10; USDA-ARS National Soil Erosion Research Laboratory: West Lafayette, IN, USA, 1995.

103. Beven, K. Changing ideas in hydrology-The case of physically-based models. J. Hydrol. 1989, 105, $157-172$. [CrossRef]

104. Zougmoré, R.; Mando, A.; Stroosnijder, L. Effect of soil and water conservation and nutrient management on the soil-plant water balance in semi-arid Burkina Faso. Agric. Water Manag. 2004, 65, 103-120. [CrossRef]

105. Lamachère, J.M.; Serpanie, G. Valorisation agricole des eaux de ruissellement et lutte contre l'érosion sur champs cultives en mil en zone soudano-sahélienne Burkina Faso-Province du Yatenga-Région de Bidi. In Utilisation Rationnelle de L'eau et des Petits Bassins Versants en Zone Aride; J. Libbey Eurotext: Paris, France, 1990; pp. 88-104. (In French)

106. Karambiri, H.; Ribolzi, O. Identification of Sediment Sources in a Small Grazed Sahelian Catchment, Burkina Faso; IAHS-AISH P291; IAHS Press: Wallingford, CT, USA, 2005.

107. Dumas, R.; Claude, J. Mesures des Transports Solides de la Volta Blanche au site de Niaogho. Campagne 1977; ORSTROM: Ouagadougou, Burkina Faso, 1977. (In French)

108. H.E.R. Service Hydrologie. Etude Hydrologique de la Kompienga: Campagne de Measures 1980; World Bank: Washington, DC, USA, 1981. (In French)

109. Mietton, M. Méthodes et efficacité de la lutte contre l'érosion hydrique au Burkina Faso. Cah ORSTOM Sér. Pédol. 1986, 12, 181-196.

110. Zougmoré, R.; Mando, A.; Stroosnijder, L.; Ouédraogo, E. Economic benefits of combining soil and water conservation measures with nutrient management in semiarid Burkina Faso. Nutr. Cycl. Agroecosyst. 2004, 70, 261. [CrossRef]

111. Frankl, A.; Poesen, J.; Deckers, J.; Haile, M.; Nyssen, J. Gully head retreat rates in the semi-arid highlands of Northern Ethiopia. Geomorphology 2012, 173-174, 185-195. [CrossRef]

112. Frankl, A.; Poesen, J.; Haile, M.; Deckers, J.; Nyssen, J. Quantifying long-term changes in gully networks and volumes in dryland environments: The case of Northern Ethiopia. Geomorphology 2013, 201, 254-263. [CrossRef]

113. Frankl, A.; Nyssen, J.; De Dapper, M.; Haile, M.; Billi, P.; Munro, N.; Deckers, J.; Poesen, J. Linking long-term gully and river channel dynamics to environmental change using repeat photography (North Ethiopia). Geomorphology 2011, 129, 238-251. [CrossRef]

114. Sawadogo, H. Impact des Aménagements sur les Systèmes de Production, les Rendements et la Sécurité Alimentaire des Exploitations Agricoles; Etude Plateau Central. Rapport de Travail No. 2; CILSS: Ouagadougou, Burkina Faso, 2003. (In French)

115. Ouedraogo, I. Land Use Dynamics and Demographic Change in Southern Burkina Faso. Ph.D. Thesis, Swedish University of Agricultural Sciences, Uppsala, Sweden, 2010.

116. Bayala, J.; Sileshi, G.W.; Kalinganire, A.; Tchoundjeu, Z.; Sinclair, F.; Garrity, D. Cereal yield response to conservation agriculture practices in drylands of West Africa: A quantitative synthesis. J. Arid Environ. 2012, 78, 13-25. [CrossRef]

117. Onyango, S. Using Agroforestry and Forestry Management to Mitigate and Adapt to Climate Change in Cassou Area, Burkina Faso. Agroforestry World, 2015. Available online: http://blog.worldagroforestry.org/index. php/2015/06/01/using-agroforestry-and-forestry-management-to-mitigate-and-adapt-to-climate-change-incassou-area-burkina-faso/ (accessed on 15 May 2017).

118. Alliance for Food Sovereignty in Africa (AFSA). Soil Water Conservation Techniques in Burkina Faso. 2015. Available online: https://www.oaklandinstitute.org/soil-and-water-conservation (accessed on 8 November 2017). 
119. Reij, C.; Thiombiano, T. Developpment Rural et Environment au Burkina Faso: La Rehabilitation de la Capacite Productive des Terroirs sur la Partie nord du Plateau Central Entre 1980 et 2001; Ambassade des Pays-Bas: Ouagadougou, Burkina Faso, 2003. (In French)

120. Grimaldi, S.; Angeluccetti, I.; Coviello, V.; Vezza, P. Cost-effectiveness of soil and water conservation measures on the catchment sediment budget-The Laaba Watershed case study, Burkina Faso. Land Degrad. Dev. 2015, 26, 737-747. [CrossRef]

121. Verstraeten, G.; Poesen, J.; De Vente, J.; Koninckx, X. Sediment variability in Spain: A quantitative and semi-quantitative analysis using reservoir sedimentation rates. Geomorphology 2003, 50, 327-348. [CrossRef]

122. Tamene, L.; Park, S.J.; Dikau, R.; Vlek, P.L.G. Reservoir siltation in the semi-arid highlands of northern Ethiopia: Sediment yield-catchment area relationship and a semi-quantitative approach for predicting sediment yield. Earth Surf. Process. Landf. 2006, 31, 1364-1383. [CrossRef]

123. Beauchemin, C.; Schoumaker, B. Migration to Cities in Burkina Faso: Does the Level of Development in Sending Areas Matter? World Dev. 2005, 33, 1129-1152. [CrossRef]

124. Black, R.; Bennett, S.R.G.; Thomas, S.M.; Beddington, J. Climate change: Migration as adaptation. Nature 2011, 478, 447-449. [CrossRef] [PubMed]

125. Scheffran, J.; Marmer, E.; Sow, P. Migration as a contribution to resilience and innovation in climate adaptation: Social networks and co-development in Northwest Africa. Appl. Geogr. 2012, 33, 119-127. [CrossRef]

126. Anarfi, J.; Kwankye, S.; Ababio, O.-M.; Tiemoko, R. Migration from and to Ghana (A Background Paper); Development Research Centre on Migration, Globalization and Poverty: University of Sussex, Brighton, UK, 2003.

127. Wouterse, F. Migration in Rural Burkina Faso; CUL Initiatives in Publishing: Ithaca, NY, USA, 2007.

128. Ouédraogo, M.; Barry, S.; Zougmoré, R.; Partey, S.; Somé, L.; Baki, G. Farmers' Willingness to Pay for Climate Information Services: Evidence from Cowpea and Sesame Producers in Northern Burkina Faso. Sustainability 2018, 10, 611. [CrossRef]

129. Millennium Ecosystem Assessment (MEA). Ecosystem and Human Well-Being: Desertification Synthesis; Island Press: Washington, DC, USA, 2005.

130. McIntyre, B.; Herren, H.; Wakhungu, J.; Watson, R. Agriculture at a Crossroads: International Assessment of Agricultural Knowledge; Science and Technology for Development (IAASTD): Washington, DC, USA, 2009.

131. Lester, M.P. Half-Moon Farming Nourishes Crops in Burkina Faso. 2016. Available online: https:/ / reliefweb. int/report/burkina-faso/half-moon-farming-nourishes-crops-burkina-faso (accessed on 7 March 2018).

132. Lee, L.K. The Impacts of Landownership Factors on Soil Conservation. Am. J. Agric. Econ. 1983, 65, 63-67. [CrossRef]

133. Besley, T. Property Rights and Investments Incentives: Theory and Evidence from Ghana. J. Political Econ. 1995, 103, 903-937. [CrossRef]

134. Feder, G.; Just, R.E.; Zilberman, D. Adoption of Agricultural Innovations in Developing Countries. Econ. Dev. Cult. Chang. 1985, 33, 255-298. [CrossRef]

135. Li, G.; Rozelle, S.; Brandt, L. Tenure, Land Rights and Farmer Investment Incentives in China. Agric. Econ. 1998, 19, 63-71. [CrossRef]

136. Lee, L.K.; Stewart, W.H. Landownership and the Adoption of Minimum Tillage. Am. J. Agric. Econ. 1983, 65, 256-264. [CrossRef]

137. Barbier, B.; Yacouba, H.; Karambiri, H.; Zoromé, M.; Somé, B. Human Vulnerability to Climate Variability in the Sahel: Farmers' Adaptation Strategies in Northern Burkina Faso. Environ. Manag. 2009, 43, 790-803. [CrossRef] [PubMed]

138. Morris, J.; Barron, J. Agricultural Water Management Technology Expansion and Impact on Crop Yields in Northern Burkina Faso (1980-2010): A Review; R4D Series 10; CGIAR Challenge Program on Water and Food: Colombo, Sri Lanka, 2014.

139. International Fund for Agricultural Development (IFAD). Burkina Faso-Programme Spécial Conservation des Eaux et des Sols-Agroforesterie (PS CES/AGF); Rapport d’Évaluation Intermédiaire, Nº1471-BF; IFAD: Rome, Italy, 2004.

140. Mahrh, D. Resultats Définitifs de la Campagne Agricole 2004/2005 (EPA); Ministere de L'agriculture Ressources Halieutiques: Ouagadougou, Burkina Faso, 2006. (In French) 
141. Auerswald, K.; Schimmack, W. Element-pool balances in soils containing significant rock fragments. Catena 2000, 40, 279-290. [CrossRef]

142. Poesen, J.; Lavee, H. Rock fragments in topsoil: Significance and processes. Catena 1994, 23, 1-28. [CrossRef]

143. Poesen, J. Surface sealing as influenced by slope angle and position of simulated stones in the toplayer of loose sediments. Earth Surf. Process. Landf. 1994, 11, 1-10. [CrossRef] 